\title{
P-I metalloproteinases and L-amino acid oxidases from Bothrops species inhibit angiogenesis
}

\author{
Shreesha K. Bhat ${ }^{1}\left(\mathbb{0}\right.$, Manjunath B. Joshi', Sampara Vasishta ${ }^{1}$, Rajesh N. Jagadale², Setlur G. Biligiri², \\ Monika A. Coronado ${ }^{3}$, Raghuvir K. Arni ${ }^{3}$, Kapaettu Satyamoorthy ${ }^{1 *}$ (1) \\ ${ }^{1}$ Manipal School of Life Sciences, Manipal Academy of Higher Education, Manipal, India. \\ ${ }^{2}$ Juggat Pharma, Jagadale Industries, Bangalore, India. \\ ${ }^{3}$ Multiuser Center for Biomolecular Innovation, Department of Physics, São Paulo State University (UNESP), São José do Rio Preto, SP, Brazil.
}

\section{Keywords:}

P-I metalloproteinases

LAAO

Bothrops

Anti-angiogenic

Snake venom

\footnotetext{
* Correspondence: ksatyamoorthy@manipal.edu https://doi.org/10.1590/1678-9199-JVATITD-2020-0180

Received: 08 December 2020; Accepted: 08 April 2021; Published online: 18 August 2021
}

\begin{abstract}
Background: Snake venoms are composed of pharmacologically active proteins that are evolutionarily diverse, stable and specific to targets. Hence, venoms have been explored as a source of bioactive molecules in treating numerous diseases. Recent evidences suggest that snake venom proteins may affect the formation of new blood vessels. Excessive angiogenesis has been implicated in several pathologies including tumours, diabetic retinopathy, arthritis, inter alia. In the present study, we have examined the effects of P-I metalloproteinases isolated from Bothrops moojeni (BmMP-1) and Bothrops atrox (BaMP-1) and L-amino acid oxidases (LAAO) isolated from B. moojeni (BmLAAO) and $B$. atrox (BaLAAO) on biochemical and functional aspects of angiogenesis.

Methods: P-I metalloproteinases and LAAO were purified from venom by molecular size exclusion and ion-exchange chromatography and subsequently confirmed using mass spectrometry. The P-I metalloproteinases were characterized by azocaseinolytic, fibrinogenolytic and gelatinase activity and LAAO activity was assessed by enzyme activity on L-amino acids. Influence of these proteins on apoptosis and cell cycle in endothelial cells was analysed by flow cytometry. The angiogenic activity was determined by in vitro 3D spheroid assay, Matrigel tube forming assay, and in vivo agarose plug transformation in mice.
\end{abstract}

Results: P-I metalloproteinases exhibited azocaseinolytic activity, cleaved $\alpha$ and partially $\beta$ chain of fibrinogen, and displayed catalytic activity on gelatin. LAAO showed differential activity on L-amino acids. Flow cytometry analysis indicated that both P-I metalloproteinases and LAAO arrested the cells in G0/G1 phase and further induced both necrosis and apoptosis in endothelial cells. In vitro, P-I metalloproteinases and LAAO exhibited significant antiangiogenic properties in 3D spheroid and Matrigel models by reducing sprout outgrowth and tube formation. Using agarose plug transplants in mice harbouring P-I metalloproteinases and LAAO we demonstrated a marked disruption of vasculature at the periphery.

Conclusion: Our research suggests that P-I metalloproteinases and LAAO exhibit anti-angiogenic properties in vitro and in vivo. 


\section{Background}

Snake venoms are a complex mixture of physiologically active proteins that makes them attractive sources of therapeutically important molecules [1]. Snake venom proteins are multifunctional, evolutionarily diverse and possess a high degree of effectiveness and stability. These properties are inviting to explore and develop novel compounds for therapeutic purposes [2]. Snakes of Bothrops genus, belonging to Viperidae family, are abundantly spread over Brazil and neighbouring countries [3]. More than $90 \%$ of proteins from Bothrops venom have been reported to interfere with several physiological processes [4]. Envenoming by Bothrops spp. is characterized by local tissue damage that includes hemorrhage, pain, edema and necrosis, and may also cause systemic disruptions such as coagulopathies and renal failure [5,6]. Major proteins of venom from Viperidae family include serine proteinases, metalloproteinases, phospholipases and L-amino acid oxidases (LAAO).

Snake venom metalloproteinases (SVMP) belong to a subfamily of enzymes called reprolysin with an ability to cleave selective key peptide bonds. Proteomic analysis showed the presence of multifunctional metalloproteinases in the venom of Crotalid and Viperid snakes [7]. SVMPs are large multidomain proteins synthesized in the venom gland with pro-enzyme domain and a conserved zinc-protease domain [8]. The secreted enzymes are categorized into P-I mature (metalloproteinase domain), P-II (metalloproteinase domain, disintegrin-like) and P-III (metalloproteinase domain, disintegrin-like, cysteine-rich) $[9,10,11]$. Several aspects of snake venom metalloproteinases (SVMP) with potential pathological effects have been studied. These includes vascular damage leading to hemorrhage [12], necrosis and poor regeneration of skeletal muscle [13], dermonecrosis and blistering [14] and the inflammatory molecules responsible for edema, pain and chemotaxis $[15,16]$. Jararhagin, a P-III metalloproteinase isolated from B. jararaca, has been widely studied for fibrinolytic action, hemorrhagic activity and degradation of ECM proteins [17]. Similarly, P-I metalloproteinases were purified and characterized with high catalytic activity on fibrin [18], kininogen [19] and degradation of extracellular matrix [20]. P-I metalloproteinases showed hemorrhagic activity [14], weak [21] or non-hemorrhagic activity [22], platelet aggregation [23], disintegration activity and apoptosis on endothelial cells by the process anoikis [24]. During envenomation, endothelial damage caused by metalloproteinases leads to poor tissue regeneration. Earlier studies have demonstrated that SVMP alter structure and function of endothelial cells [11].

$\mathrm{L}$-amino acid oxidase (LAAO) is a flavoenzyme that catalyzes the oxidative deamination of L-amino acid substrate into an a-keto acid along with the formation of hydrogen peroxide $\left(\mathrm{H}_{2} \mathrm{O}_{2}\right)$ and ammonia $\left(\mathrm{NH}_{3}\right)$. The snake venom LAAO depends on flavin adenine dinucleotide (FAD) molecule and is responsible for the toxicity as a consequence of $\mathrm{H}_{2} \mathrm{O}_{2}$ produced during the transiently reduced flavin cofactor reoxidation by molecular oxygen $[25,26]$. LAAO, a major toxin present in the viper venom, have been demonstrated to possess cytotoxic activity. Using a battery of cell and biochemical assays in vitro, studies have shown anti-tumour properties of snake venom-LAAO (SV-LAAO) in various cancer cell lines such as MCF-7 and SKBR-3 (breast adenocarcinoma cells) [27,28] and melanoma [29] S-180 (murine sarcoma 180) [27]. LAAO are also capable of inducing apoptosis on endothelial cells [30], leukemic cells [31], keratinocytes [32] and other several cells types by inducing oxidative stress, which is critical in supressing the tumour growth. Over the years, studies have indicated that reactive oxygen species (ROS) damage the cell membrane lipids and may cause potential cytotoxicity [33,34]. As cellular membrane of tumour cells are composed of higher levels of lipids compared to the normal cells, $\mathrm{H}_{2} \mathrm{O}_{2}$ produced by SV-LAAOs may cause a direct and specific effect on tumour cells [35].

Angiogenesis is one of the key processes involved in the remodelling of the tissue microenvironment. Tissue remodelling is a complex process that involves the development of new capillaries from pre-existing blood vessels. Angiogenesis engage in various normal physiological processes, such as wound healing, female menstrual cycle and bone remodelling. In contrast, several pathological conditions are also accompanied with undesirable neovascularization, including tumour growth, metastasis, diabetic retinopathy and inflammatory diseases [36]. Angiogenesis is a pre-requisite in solid tumours to enable their growth and metastasis. Therefore, impeding the growth of blood vessels in the tumour microenvironment comprises an attractive therapeutic strategy. Accordingly, identification of molecules showing anti-angiogenic properties have gained clinical importance [37]. Several biomolecules exhibiting anti-angiogenic activity are currently being studied, naturally including few components of snake venom [38].

Hence, in the present study we have (i) isolated the P-I metalloproteinases (BmMP-1 from B. moojeni and BaMP-1 from B. atrox) and LAAO (BmLAAO from B. moojeni and BaLAAO from $B$. atrox) proteins from venom, (ii) characterized these proteins by batteries of biochemical activities and (iii) examined their ability to modulate angiogenesis in vitro and in vivo.

\section{Methods}

\section{Chemicals}

Azocaesin, methylcellulose and fibrinogen were obtained from Sigma-Aldrich (St Louis, USA). Collagen R solution, Matrigel and basic fibroblast growth factor (bFGF) were obtained from SERVA electrophoresis (Heidelberg, Germany), BD biosciences (San Jose, USA) and R \& D systems (Minneapolis, USA) respectively. The crude venom samples of $B$. moojeni and $B$. atrox were purchased from San Maru Serpentarium, Brazil, and their use was approved by the Brazilian Institute of the Environment and Renewable Natural Resources (Ibama). Purification columns Superdex 200 column and Mono Q 5/50 were purchased from GE Healthcare (Little Chalfont, UK). 


\section{Molecular size exclusion chromatography}

Bothrops venom ( $25 \mathrm{mg}$ ) was separately dissolved in $0.6 \mathrm{~mL}$ of a $0.02 \mathrm{M}$ sodium acetate buffer $\mathrm{pH} 7.3$ containing $0.1 \mathrm{M} \mathrm{NaCl}$ and centrifuged at $10,000 \times \mathrm{g}$ for 5 minutes. The supernatant was applied into a Superdex 200 column, previously equilibrated with the same buffer. The protein fractions were collected every minute at the flow rate of $0.4 \mathrm{~mL} / \mathrm{min}$, which was monitored at $280 \mathrm{~nm}$.

\section{lon-exchange chromatography}

The fractions containing P-I metalloproteinase and LAAO from molecular size exclusion chromatography were pooled separately and applied onto a Mono Q 5/50 GL column, previously equilibrated with $0.02 \mathrm{M}$ Tris- $\mathrm{HCl} \mathrm{pH} 8.2$ and $0.02 \mathrm{M}$ HEPES pH 7.5 buffers, respectively. The bound protein fractions were eluted with a non-linear gradient with $0.02 \mathrm{M}$ Tris- $\mathrm{HCl} \mathrm{pH}$ 8.2 containing $1 \mathrm{M} \mathrm{NaCl}$ with the flow rate of $0.5 \mathrm{~mL} / \mathrm{minute}$, monitored at $280 \mathrm{~nm}$. All the peak fractions were concentrated, and the purity was evaluated by $10 \%$ sodium dodecyl sulphate polyacrylamide gel electrophoresis (SDS-PAGE).

\section{Peptide mass fingerprinting of P-I metalloproteinases and LAAO}

Peptide fingerprints of P-I metalloproteinases and LAAO were determined using liquid chromatography/mass spectrometry as described in our earlier [39]. The purified protein was run on SDS PAGE and was stained with Coomassie brilliant blue R-250. The protein bands were sliced, treated with $5 \mathrm{mM}$ DTT and the gel pieces were immersed in $55 \mathrm{mM}$ iodoacetamide and incubated in the dark for 30 minutes. This was followed by washes with ammonium bicarbonate $\left(\mathrm{NH}_{4} \mathrm{HCO}_{3}\right)$ and acetonitrile. The gel pieces were vacuum dried and incubated with $5 \mathrm{mg} / \mathrm{mL}$ trypsin in $\mathrm{NH}_{4} \mathrm{HCO}_{3}$ and incubated at $37^{\circ} \mathrm{C}$ overnight. Subsequently, the peptide extraction was performed stepwise by treating the gel pieces with (i) $30 \%$ acetonitrile in $1 \%$ trifluoro acetic acid (TFA), (ii) $1 \%$ TFA and (iii) $70 \%$ acetonitrile with $1 \%$ TFA. In each step, 30 minutes of vortex and 3 minutes of sonication were performed before collecting the supernatant. Supernatant collected from each step was combined, dried in vacuum and reconstituted with acetonitrile. Tryptic digested sample $(8 \mu \mathrm{L})$ was injected into HPLC coupled with Agilent 6520 accurate-mass Q-TOF LC/MS using a reverse phase eclipse plus C18 column, $5 \mu \mathrm{m}$, $4.6 \mathrm{~mm}$ X $150 \mathrm{~mm}$ (Agilent Technologies, Santa Clara, US) and peptides were eluted in gradient form with $30-70 \%$ acetonitrile gradient. MS/MS analysis was performed, peaks obtained were processed and converted to Mascot generating file (.MGF) using Qualitative Mass Hunter (Agilent Technologies). The .MGF files were processed in Mascot database version 2.3 (Matrix Science Limited, London, UK). Proteins were identified using the following parameters: enzyme as trypsin, carbamidomethylation as fixed modification, methionine oxidation as variable modification and with peptide charges more than $3+$. Peptide blast was performed using Swiss Prot database.

\section{Azocaseinolytic activity of metalloproteinases}

For characterization of P-I metalloproteinases, either BmMP-1 or BaMP-1 $(2 \mu \mathrm{g})$ was incubated with azocasein $(1.5 \mathrm{mg} / \mathrm{mL})$ in $0.5 \%$ Sodium carbonate containing $5 \mathrm{mM} \mathrm{CaCl}_{2}$ and incubated at $37^{\circ} \mathrm{C}$ for 60 minutes [40]. Further, $100 \mu \mathrm{L}$ of $20 \%$ (v/v) trichloroacetic acid (TCA) was added and incubated for 30 minutes on ice, followed by centrifugation for 15 minutes. For $1 \mathrm{~mL}$ of supernatant, $500 \mu \mathrm{L}$ of $1 \mathrm{M} \mathrm{NaOH}$ was added and absorbance of the supernatant was determined at $405 \mathrm{~nm}$ using Varioskan ${ }^{\mathrm{Tm}}$ LUX multimode microplate reader (Thermo Fisher Scientific, USA). Further, the effect of inhibitors (EDTA, EGTA, PMSF, 1,10 Phenanthroline, $\mathrm{CaCl}_{2}, \mathrm{ZnCl}_{2}, \mathrm{MgCl}_{2}$ and $\left.\mathrm{HgCl}_{2}\right),(10 \mathrm{mM}$, each) was tested on P-I metalloproteinases by incubating for 30 minutes at $37^{\circ} \mathrm{C}$.

\section{Fibrinogenolytic activity}

The fibrinogenolytic activity of BmMP-1 or BaMP-1 $(2 \mu \mathrm{g} / \mathrm{mL})$ was determined by incubating with $10 \mu \mathrm{g}$ of fibrinogen in $0.1 \mathrm{M}$ Tris$\mathrm{HCl}$ buffer $\mathrm{pH} 7.4$ (30 $\mu \mathrm{L}$ reaction mixture) for $2 \mathrm{~h}$ at $37^{\circ} \mathrm{C}$ [41]. Laemmli buffer was added to stop the reaction and analysed on $10 \%$ SDS PAGE for the degradation of sub-units of fibrinogen.

\section{Gelatinase activity}

To assess gelatinase activity, either BmMP-1 or BaMP-1 ( $1 \mu \mathrm{g}$ / lane) were separated on $10 \%$ SDS PAGE containing $0.3 \%$ gelatin as a substrate [41]. The gel was incubated for 90 minutes with renaturation buffer $(0.5 \%$ Triton $\mathrm{X}-100)$ and developing buffer (10 mM Tris pH 7.8, 5mM CaCl, $100 \mathrm{mM} \mathrm{NaCl}$ ) for $16-20 \mathrm{~h}$. Further, the gel was stained with Coomassie brilliant blue G-250 and the activity was observed for a clear zone in the gel.

\section{Enzyme activity of LAAO}

The LAAO activity was measured by the initial rate of $\mathrm{H}_{2} \mathrm{O}_{2}$ production with peroxidase/dye assay [42]. The assay mixture contained either BmLAAO or BaLAAO $(2 \mu \mathrm{g}), 0.01 \mathrm{M} \mathrm{L}$-amino acid, $0.2 \mathrm{M}$ Tris- $\mathrm{HCl}$ buffer $\mathrm{pH} 8.0,0.2 \mathrm{mg} / \mathrm{mL}$ o-dianisidine hydrochloride, $1 \mathrm{U} / \mathrm{mL}$ horseradish peroxidase. Further, the reaction mixture was incubated at $30^{\circ} \mathrm{C}$ for $1 \mathrm{~h}$ and the dye formation was measured spectrophotometrically at $410 \mathrm{~nm}$ in a $\operatorname{Varioskan}^{\mathrm{TN}}$ LUX multimode microplate reader (Thermo Fisher Scientific, USA). Further, the effect of divalent metal ions $\left(\mathrm{CaCl}_{2}\right.$, $\mathrm{ZnCl}_{2}, \mathrm{MgCl}_{2}, \mathrm{HgCl}_{2}-10 \mathrm{mM}$ each) and amino acid derivative $\mathrm{N}$-acetyl cysteine $(5 \mathrm{mM})$, was tested on LAAO activity using L-Leu, L-Met, L-His, L-Tyr and L-Trp as substrates by incubating for 30 minutes at $37^{\circ} \mathrm{C}$.

\section{Cell culture}

Endothelial cells (HUVECs) were cultured in Endothelial Cell Growth Medium (ECGM) along with endothelial supplements containing 5\% Fetal bovine serum (FBS - Promo cell GMBH, Germany) on gelatin coated plates maintained at $37^{\circ} \mathrm{C}$ with $5 \% \mathrm{CO}_{2}$. Fibroblast cells cultured in DMEM supplemented with 10\% FBS (HiMedia, India) at $37^{\circ} \mathrm{C}$ with $5 \% \mathrm{CO}_{2}$ as described previously [39]. HepG2 cells (ATCC) were cultured in DMEM 10\% FBS. 


\section{MTT assay}

MTT based cytotoxicity assay was performed on HUVECs, fibroblasts and HepG2. The cells were seeded at the density of 10,000 cells/well in a 96 well plate. The endothelial cells were treated with different concentration BmMP-1 or BaMP-1 (0.5 $\mu \mathrm{g} / \mathrm{mL}, 1 \mu \mathrm{g} / \mathrm{mL}, 2 \mu \mathrm{g} / \mathrm{mL}, 3 \mu \mathrm{g} / \mathrm{mL}$ ) or BmLAAO or BaLAAO (1 ng/mL, $10 \mathrm{ng} / \mathrm{mL}, 100 \mathrm{ng} / \mathrm{mL}, 200 \mathrm{ng} / \mathrm{mL}$ ) or mitomycin $(50 \mu \mathrm{g} / \mathrm{mL})$ maintained at $37^{\circ} \mathrm{C}$ with $5 \% \mathrm{CO}_{2}$ for $24 \mathrm{~h}$. For Fibroblast and HepG2 treated with BmMP-1 or BaMP-1 $(2 \mu \mathrm{g} / \mathrm{mL})$ and BmLAAO or BaLAAO $(100 \mathrm{ng} / \mathrm{mL})$ maintained at $37^{\circ} \mathrm{C}$ with $5 \% \mathrm{CO}_{2}$ for $24 \mathrm{~h}$. After the incubation, $20 \mathrm{~mL}$ of $5 \mathrm{mg} / \mathrm{mL}$ MTT was added and incubated for $4 \mathrm{~h}$. DMSO (100 $\mu \mathrm{L}$ ) was added to dissolve Formazan crystals and absorbance $570 \mathrm{~nm}$ was noted using Varioskan ${ }^{\mathrm{TM}}$ flash multimode reader (Thermo Scientific, USA).

\section{Three-dimensional collagen spheroid assay}

Endothelial cells were resuspended in basal ECGM containing $20 \%$ of methylcellulose. The cell solution was dispensed on noncell culture treated surface of petri dishes to obtain 5000 cells/ drop and incubated at $37^{\circ} \mathrm{C}$ with $5 \% \mathrm{CO}_{2}$ for $24 \mathrm{~h}$. The spheroids formed in each drop were implanted within the collagen matrix with different concentrations of BmMP-1 or BaMP-1 (0.5 $\mu \mathrm{g}$ / $\mathrm{mL}, 1 \mu \mathrm{g} / \mathrm{mL}$ and $2 \mu \mathrm{g} / \mathrm{mL}) / \mathrm{BmLAAO}$ or BaLAAO $(1 \mathrm{ng} / \mathrm{mL}$, $10 \mathrm{ng} / \mathrm{mL}$ and $100 \mathrm{ng} / \mathrm{mL}) / \mathrm{bFGF}(10 \mathrm{ng} / \mathrm{mL}) / \mathrm{PBS}$ and cultured for $24 \mathrm{~h}$. The length of sprouts per spheroid was measured morphologically by using ImageJ software (NIH, USA).

\section{Tube forming assay}

Matrigel $(50 \mu \mathrm{L})$ was coated on 96 -well plate allowed to solidify at $37^{\circ} \mathrm{C}$ for $1 \mathrm{~h}$. HUVECs were seeded on Matrigel cushion at the density of $2 \times 10^{4}$ cells/well. Then the cells were treated with $2 \mu \mathrm{g} / \mathrm{mL}$ of BmMP-1 or BaMP-1, $100 \mathrm{ng} / \mathrm{mL}$ of BmLAAO or BaLAAO, $10 \mathrm{ng} / \mathrm{mL}$ of bFGF and PBS (Control) and incubated at $37^{\circ} \mathrm{C}$ with $5 \% \mathrm{CO}_{2}$ for $6 \mathrm{~h}$. Kinetics of tube formation at different time points was observed and counted.

\section{Cell cycle analysis}

The HUVECs were seeded onto 6 well plate at the density of $10^{5}$ cells/mL and incubated to grow to $80 \%$ confluency. The HUVECs were washed twice with PBS and serum starved (0.5\% FBS) for $4 \mathrm{~h}$. Further, the cells were treated with $2 \mu \mathrm{g} / \mathrm{mL}$ of BmMP- 1 or BaMP-1 and $100 \mathrm{ng} / \mathrm{mL}$ of BmLAAO or BaLAAO for $12 \mathrm{~h}$. After the incubation, the cells were trypsinized and centrifuged for 3 minutes. Single cell suspension was fixed upon adding $70 \%$ ethanol drop by drop and incubated in $4^{\circ} \mathrm{C}$ for $1 \mathrm{~h}$. The pellet was washed with PBS and RNAase $(0.5 \mu \mathrm{g} / \mathrm{mL})$ was added to the pellet and further incubated at $37^{\circ} \mathrm{C}$ for $1 \mathrm{~h}$. Propidium iodide $(10 \mu \mathrm{g} / \mathrm{mL})$ in PBS was added to the pellet and incubated on ice for 20 minutes. This suspension was passed through flow cytometer (Sysmex Partec, Germany) and data were analysed using cyFlow software (Sysmex Partec, Germany).

\section{Annexin V/propidium iodide (PI) staining}

The HUVECs were treated as mentioned in cell cycle analysis. After treatment, the cells were trypsinized and centrifuged for 3 minutes for $800 \mathrm{rpm}$ for 5 minutes. Further, Annexin $\mathrm{V}$ analysis was performed using FITC Annexin V Apoptosis Detection Kit (BD Biosciences, 556547). This suspension was passed through flow cytometer (Sysmex Partec, Germany) and data were analysed using cyFlow software (Sysmex Partec, Germany).

\section{Agarose plug transplantation assay}

The animal experiments were conducted upon approval from Institutional Animal Ethics Committee (IAEC), Manipal Academy of Higher Education, Manipal (IAEC/KMC/48/2015). Animal handling in the present study was accordance with the standard guidelines of the committee for the purpose of control and supervision on experiments on animals (CPCSEA), Government of India. The animals were nurtured in sterile polypropylene cages and maintained in control conditions as follows: Temperature $23 \pm 2{ }^{\circ} \mathrm{C}$, humidity $50 \pm 5 \%$ and $12 \mathrm{~h}$ light/dark cycle, access to sterile water and food ad libitum. The agarose plug transplantation assay was performed as described earlier [24], to demonstrate the effect of P-I metalloproteinases and LAAO proteins on angiogenesis in vivo. Swiss albino mice (6-8 weeks, 25-30 g) were randomly used in six groups; control, bFGF, BmMP-1, BaMP-1, BmLAAO and BaLAAO ( $n=6$ in each group). Before the insertion of agarose plug, mice were anesthetized with Ketamine-anket $(65 \mathrm{mg} / \mathrm{kg})$ and DiazepamCalmpose (8 mg/kg). BmMP-1 or BaMP-1 (5 $\mu \mathrm{g} / \mathrm{mL}) /$ BmLAAO or BaLAAO $(1 \mu \mathrm{g} / \mathrm{mL}) / \mathrm{bFGF}(100 \mathrm{ng} / \mathrm{mL}) / \mathrm{PBS}$ was mixed with agarose gel $(2 \%, 50 \mu \mathrm{L})$ and was allowed to solidify. Then the agarose pellet was introduced into subcutaneous space of mice under sterile condition and the animals were in-housed for five days in our institutional animal house in central animal research facility (CARF), following the animal was euthanized with standard procedure. Further, the tissues were excised and photographed with the surrounding skin.

\section{Statistical analysis}

All the experiments were performed in triplicates independently. Unpaired two-tailed Student t-test and ANOVA were performed with or without post-hoc tests using GraphPad Prism (Version 8). Continuous data were represented as mean \pm standard deviations (SD) and p-value $<0.05$ was considered as a significant change.

\section{Results}

\section{Purification and characterization of $\mathbf{P}-\mathbf{I}$ metalloproteinases and LAAO}

P-I metalloproteinases and LAAOs were purified from crude venoms of $B$. atrox and B. moojeni by molecular size exclusion and ion-exchange chromatography. Figure 1 shows the separation of P-I metalloproteinases and LAAO by ion-exchange chromatography. 
P-I metalloproteinases isolated from B. moojeni (BmMP-1) and B. atrox (BaMP-1) showed molecular weight of $\sim 25 \mathrm{kDa}$ on SDS PAGE (10\%) which is in agreement with P-I metalloproteinases isolated from Bothrops spp. in earlier studies as summarized in Table 1 (Fig. 1A and 1B). The molecular weight of LAAO isolated from B. moojeni (BmLAAO) and B. atrox (BaLAAO) was $\sim 58$ $\mathrm{kDa}$ on SDS PAGE (10\%) which is in accordance with the protein isolated from different Bothrops spp. (Table 2) (Fig. 1C and 1D).

Further, P-I metalloproteinases and LAAO were characterized by mass spectrometry analysis. Positive mode ionization of BmMP-1 detected eight peptides matching to VM3BOP protein of $B$. jararaca with $11 \%$ coverage and a score of 422 . BaMP-1 detected five peptides matching to that of B. jararaca with $30 \%$ coverage and a score of 784 as shown in Table 3. For BaLAAO, we obtained ten peptides with precise homology to LAAO of $B$. jararaca with coverage of $40 \%$ and possessing a highly significant score of 2088. Further, BmLAAO detected nine peptides homologous to $B$. moojeni, with a score of 572 and coverage of $30 \%$ as shown in Table 4.

\section{Biochemical characterization of P-I metalloproteinases}

We characterized P-I metalloproteinases isolated from Bothrops spp. by caseinolytic assay using azocasein as the substrate. P-I metalloproteinases isolated from B. moojeni and B. atrox significantly hydrolysed the azocaesin. However, BmMP1 exhibited the highest activity when compared to BaMP-1. Further, the metalloproteinase activity was inhibited by metal chelators such as EDTA and EGTA and also protease inhibitor 1, 10 phenanthroline. However, PMSF, another class of protease inhibitor did not affect the activity of the protein. Divalent metal ions such as $\mathrm{Zn}^{+2}$ and $\mathrm{Hg}^{+2}$ were able to inhibit $40-50 \%$ of the activity, but $\mathrm{Mg}^{+2}$ and $\mathrm{Ca}^{+2}$ did not show any effect. $\beta$-mercaptoethanol significantly inhibited the activity of protein, suggesting that reduced activity may be due to the changes in the conformation of the protein due to the reduction of cysteine disulfide bonds (Fig. 2A and 2B).

To assess the gelatinolytic activity of P-I metalloproteinases, we performed gelatin zymography. BmMP-1 and BaMP-1
A

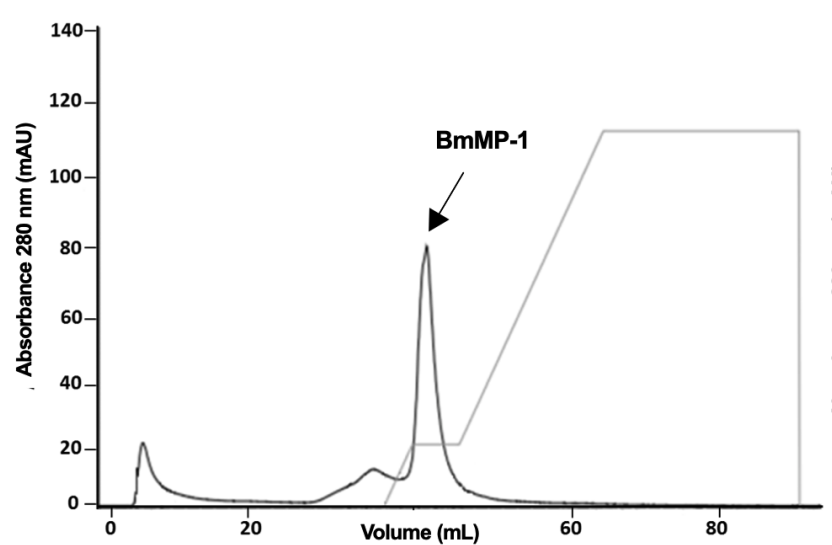

C

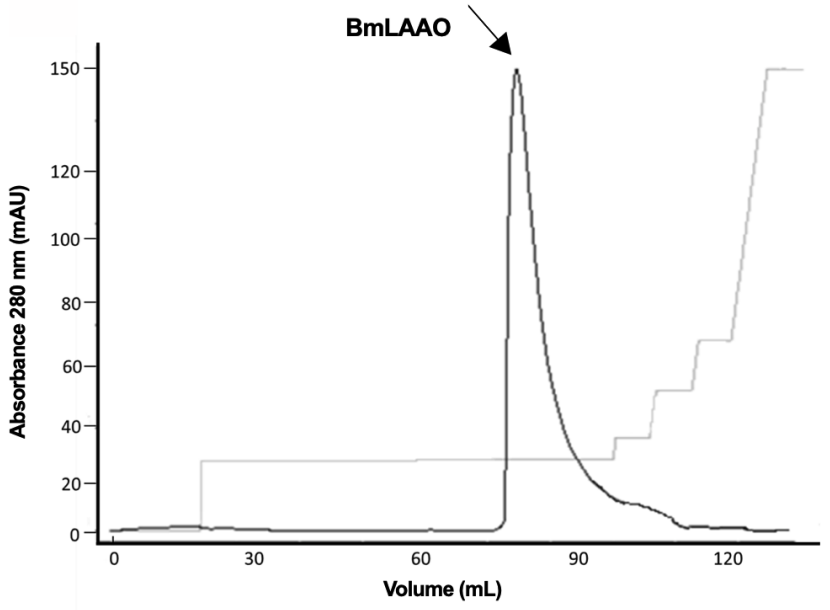

B
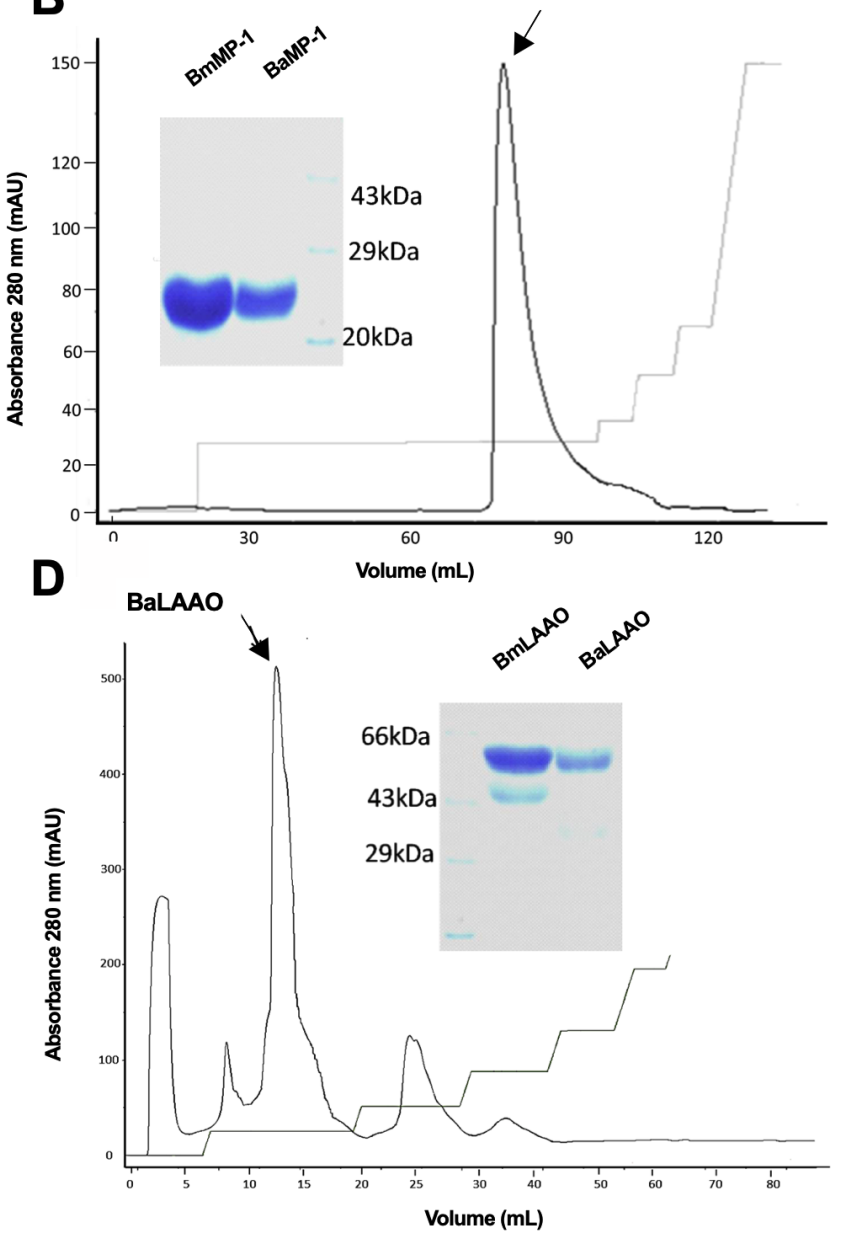

Figure 1. Purification of P-I metalloproteinases and LAAO from Bothrops venom. Peaks from size exclusion chromatography related to $P$-I metalloproteinases and LAAO were applied to the column and elution was carried out with $\mathrm{NaCl}$ gradient buffer. Peaks corresponding to respective proteins (A) BmMP-1, (B) BaMP-1, (C) BmLAAO and (D) BaLAAO are denoted by arrows. Inset: SDS-PAGE analysis of BmMP-1 and BaMP-1 and BmLAAO and BaLAAO. 
Table 1. Comparison of biochemical properties of $\mathrm{P}-\mathrm{I}$ metalloproteinases isolated from different snakes.

\begin{tabular}{|c|c|c|c|c|c|c|}
\hline Protein & Species & MW & Azocasein & Fibrinogenolytic & Gelatinolytic & Reference \\
\hline $\mathrm{BaP1}$ & B.asper & 25 & + & + & - & [49] \\
\hline Crotalin & Crotalus atrox & 25 & - & + & - & {$[74]$} \\
\hline Triflamp & $\begin{array}{l}\text { Trimeresurus } \\
\text { flavoviridis }\end{array}$ & 25 & + & + & - & {$[75]$} \\
\hline Batx-I & B. atrox & 23.29 & + & + & - & {$[43]$} \\
\hline BmooMP-I & B. moojeni & $\sim 25$ & - & + & + & {$[48]$} \\
\hline Botroxase & B. atrox & 22.9 & - & + & - & {$[76]$} \\
\hline BpirMp & B. pirajai & 23.1 & - & + & - & {$[77]$} \\
\hline
\end{tabular}

+ Determined; - not determined.

Table 2. Comparison of functional properties of LAAO isolated from different Bothrops spp.

\section{Enzyme activity of LAAO}

Amino acids

$\begin{array}{cc}\text { Bpir } & \text { Bp-LAAO, [78] } \\ \text { LAAO-1, [58] } & (\mathrm{MW}-58 \mathrm{kDa}) \\ (\mathrm{MW}-66 \mathrm{kDa}) & \end{array}$

$\begin{array}{cc}\mathrm{Lm} & \text { BmLAAO, Present } \\ \text { LAAO, }[79] & \text { study } \\ (\mathrm{MW}-60 \mathrm{kDa}) & (\mathrm{MW}-58 \mathrm{kDa})\end{array}$

$(\mathrm{MW}-58 \mathrm{kDa})$
BaLAAO,

Present study

$(\mathrm{MW}-58 \mathrm{kDa})$

\begin{tabular}{|c|c|c|c|c|c|}
\hline L-Ala & $\rightarrow$ & $\downarrow$ & ND & $\downarrow$ & $\downarrow$ \\
\hline L-Gly & $\downarrow$ & ND & ND & $\downarrow$ & $\downarrow$ \\
\hline L-lle & $\uparrow$ & $\uparrow$ & $\uparrow$ & $\downarrow$ & $\rightarrow$ \\
\hline L-Leu & $\uparrow$ & $\uparrow$ & $\uparrow$ & $\uparrow$ & $\uparrow$ \\
\hline L-Pro & $\rightarrow$ & $\downarrow$ & ND & $\downarrow$ & $\downarrow$ \\
\hline L-Val & $\uparrow$ & $\rightarrow$ & $\rightarrow$ & $\uparrow$ & $\rightarrow$ \\
\hline L-Phe & $\uparrow$ & $\uparrow$ & $\uparrow$ & $\uparrow$ & $\rightarrow$ \\
\hline L-Trp & $\uparrow$ & $\uparrow$ & $\uparrow$ & $\uparrow$ & $\rightarrow$ \\
\hline L-Tyr & $\uparrow$ & $\rightarrow$ & $\uparrow$ & $\uparrow$ & $\rightarrow$ \\
\hline L-Asp & ND & ND & ND & ND & ND \\
\hline L-Glu & $\downarrow$ & $\downarrow$ & ND & ND & ND \\
\hline L-Arg & $\rightarrow$ & $\uparrow$ & $\rightarrow$ & $\rightarrow$ & $\rightarrow$ \\
\hline L-His & $\uparrow$ & $\uparrow$ & $\rightarrow$ & $\uparrow$ & $\uparrow$ \\
\hline L-Lys & $\downarrow$ & ND & $\downarrow$ & $\rightarrow$ & $\downarrow$ \\
\hline L-Ser & $\downarrow$ & $\downarrow$ & $\downarrow$ & $\downarrow$ & $\downarrow$ \\
\hline L-Thr & $\downarrow$ & $\downarrow$ & ND & $\downarrow$ & $\downarrow$ \\
\hline L-Cys & ND & $\downarrow$ & $\downarrow$ & $\downarrow$ & $\downarrow$ \\
\hline L-Met & $\uparrow$ & $\uparrow$ & $\uparrow$ & $\uparrow$ & $\uparrow$ \\
\hline L-Asn & ND & ND & ND & $\rightarrow$ & $\downarrow$ \\
\hline L-Gln & ND & ND & ND & $\downarrow$ & $\downarrow$ \\
\hline
\end{tabular}

ヤ High activity; $\rightarrow$ moderate activity; $\boldsymbol{\Downarrow}$ low activity; ND: not determined. 
Table 3. Peptide mass fingerprinting of BmMP-1 and BaMP-1.

\begin{tabular}{ccccc}
\hline Sample & $\begin{array}{c}\text { Mascot } \\
\text { score }\end{array}$ & $\begin{array}{c}\text { Protein } \\
\text { name }\end{array}$ & $\begin{array}{c}\text { Accession } \\
\text { ID }\end{array}$ & Observed peptide sequence \\
\hline
\end{tabular}

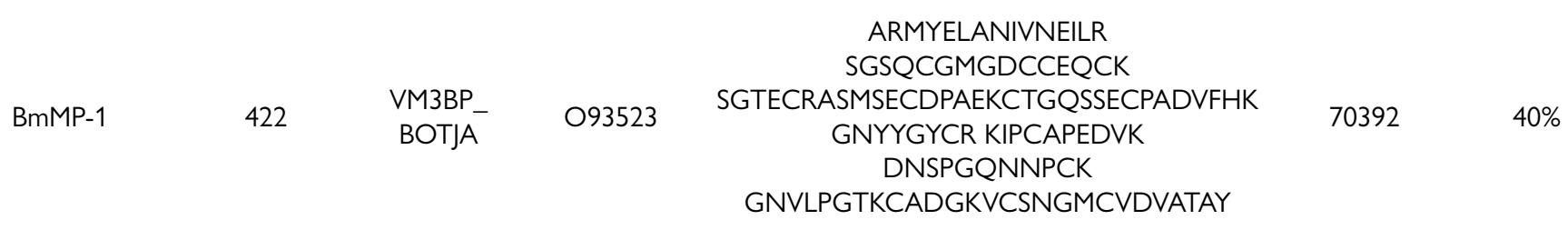

ITVKPDVDYTLNSFAEWRKTDLLTR

SGTECR GNYYGYCR

KIPCAPEDVK

DNSPGQNNPCK

GMVLPGTKCADGK

$70392 \quad 11 \%$

Table 4. Peptide mass fingerprinting of BmLAAO and BaLAAO.

\begin{tabular}{|c|c|c|c|c|c|c|}
\hline Sample & $\begin{array}{l}\text { Mascot } \\
\text { score }\end{array}$ & $\begin{array}{c}\text { Protein } \\
\text { name }\end{array}$ & $\begin{array}{c}\text { Accession } \\
\text { ID }\end{array}$ & Observed peptide sequence & $\begin{array}{l}\text { MW } \\
\text { (Da) }\end{array}$ & $\begin{array}{l}\text { Sequence } \\
\text { coverage }\end{array}$ \\
\hline BaLAAO & 2088 & $\begin{array}{l}\text { OXLA_- } \\
\text { BOTJR }\end{array}$ & Q6TGQ9 & $\begin{array}{c}\text { NPLEECFR } \\
\text { NGLSTTSNPK } \\
\text { EGWYANLGPMR } \\
\text { VGEVNKDPGVLDYPVKPSEVGKSAGQKAVEELRR } \\
\text { YDTYSTKEYLLK } \\
\text { MDDIFAYEKRFDEIVGGMDKLPTSMYQAIAEKVKLHAR } \\
\text { IQQDVKEVTVTYQTSEK } \\
\text { IKFEPPLPPKKAHALRSVHYR I } \\
\text { FLTCTKKFWE }\end{array}$ & 56595 & $40 \%$ \\
\hline BmLAAO & 576 & $\begin{array}{l}\text { OXLA_- } \\
\text { BOTMO }\end{array}$ & Q6TGQ8 & $\begin{array}{c}\text { ETDYEEFLEIAK } \\
\text { EGWYANLGPMRVGEVNKDPGVLEYPVKPSEVGKSAGQLYEESLQKAVEELR } \\
\text { YDTYSTKEYLLK } \\
\text { HDDIFAYEK } \\
\text { FDEIVGGMDKLPTSMYQAIAEK } \\
\text { IQQDVK } \\
\text { KAHALR } \\
\text { IFLTCTKKFWEDDGIHGGKSTTDLPSR }\end{array}$ & 54858 & $30 \%$ \\
\hline
\end{tabular}

showed a zone of clearance on gelatin gel signifying potential gelatinolytic activity (Fig. 2C). Our analysis revealed that P-I metalloproteinases from B. atrox and B. moojeni cleaved $\alpha$ chain and partially $\beta$ chain of fibrinogen (Fig. 2D) (Table 1).

\section{Biochemical characterization of LAAO}

The LAAO activity was determined by quantifying the initial rate of $\mathrm{H}_{2} \mathrm{O}_{2}$ production in the combination of peroxidase/ dye assay. The activity of the protein was proportionate to the formation of dye by the catalytic activity of the protein, which was then read at $410 \mathrm{~nm}$. The assay revealed that LAAO isolated from both species had displayed differential enzyme activity. BmLAAO showed high specificity towards L-Leu L-Met L-His L-Trp L-Tyr L-Phe L-Val, moderate to L-Lys L-Arg L-Asn and low specificity to L-Ile L-Ala L-Gly L-Gln L-Thr L-Ser L-Pro L-Cys L-Cystine; BaLAAO exhibited had high specific activity towards L-Met, L-Leu, L-His, moderate activity towards L-Phe, L-Tyr, L-Arg, L-Ile, L-Val and low activity towards L-Ala, L-Lys, L-Pro, 
A

\section{BmMP-1}

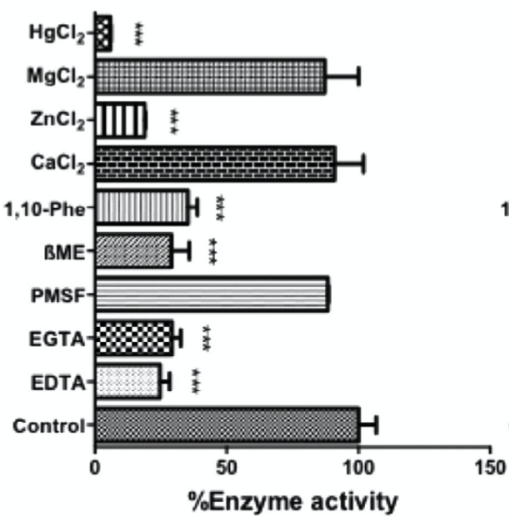

E

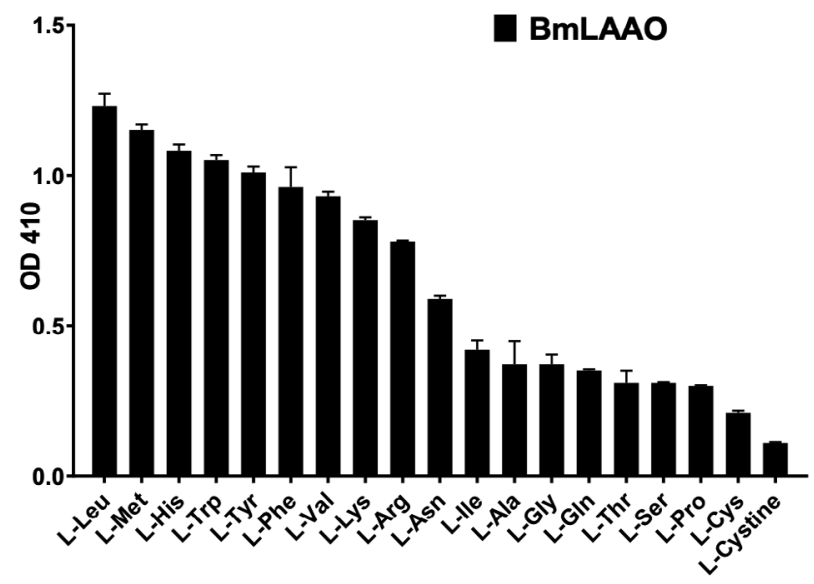

Amino acid
B

\section{BaMP-1}

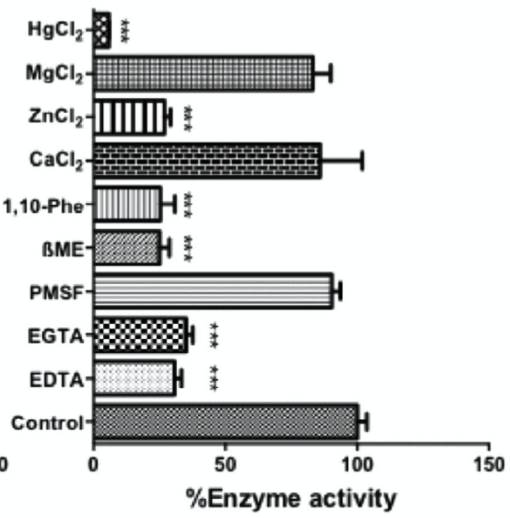

C

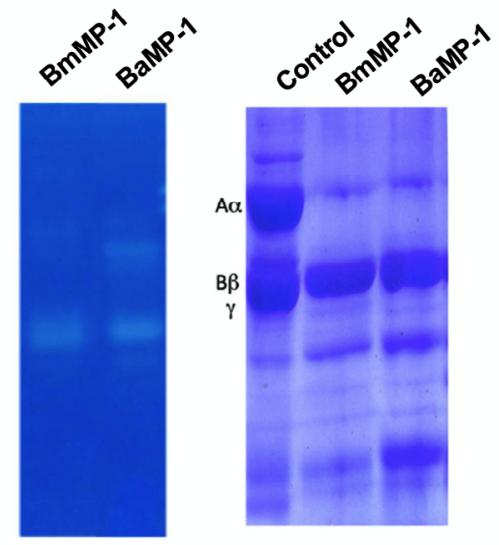

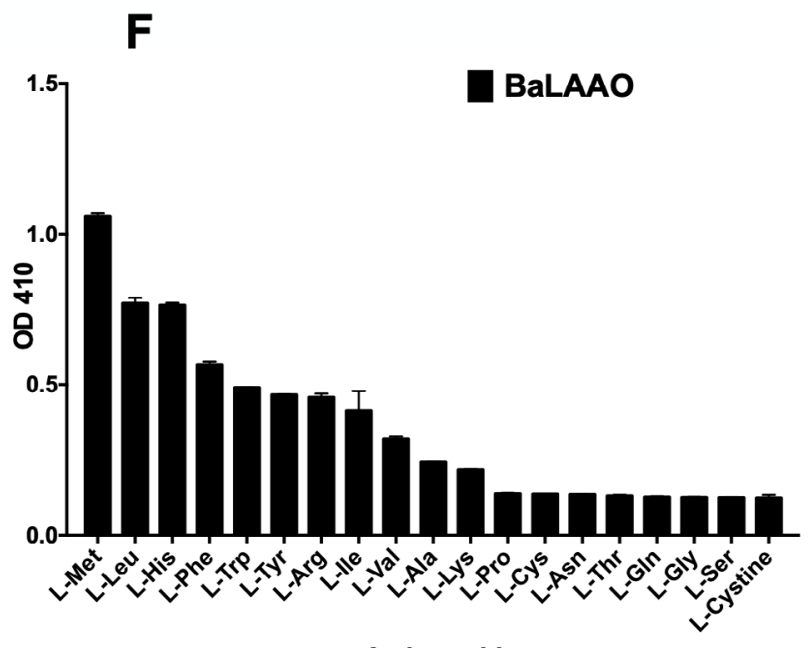

Amino acid

Figure 2. Biochemical characterization of P-I metalloproteinases and LAAO. (A) and (B) Azocaseinolytic activity of BmMP-1 and BaMP-1. Effect of inhibitors $(10 \mathrm{mM})$, metal chelators (EDTA and EGTA), divalent metals $\left(\mathrm{CaCl}_{2}, \mathrm{ZnCl}_{2}, \mathrm{MgCl}_{2}\right.$ and $\left.\mathrm{HgCl}_{2}\right)$, protease inhibitors $(1,10$ phenanthroline and PMSF) and reducing agent ( $\beta$-mercaptoethanol) on azocaseinolytic activity in the presence of BmMP-1 or BaMP-1. The data are represented as percentage of untreated control and statistical significance is indicated by asterisk ***p < 0.001. (C) BmMP-1 or BaMP-1 degraded gelatin on SDS-PAGE indicted by zone of clearance. (D) Fibrinogen $(10 \mu \mathrm{g})$ was treated with BmMP-1 or BaMP-1 and degradation of a chain and partial degradation of $\beta$ chain were observed on SDS-PAGE. L-amino acids (10 mM) were treated with (E) BmLAAO (2 $\mu \mathrm{g})$ or (F) BaLAAO $(2 \mu \mathrm{g})$ coupled with o-dianisidine HCL/HRP. The activity was measured spectrophotometrically at $410 \mathrm{~nm}$. The data are shown as arbitrary units.

L-Cys, L-Asn, L-Thr, LGln, L-Gly L-Ser, L-Cystine (Fig. 2E and 2F) (Table 2). This indicated that the specificity towards amino acid substrates varied from two different species of Bothrops. Further, we examined inhibotory effects of $\mathrm{CaCl}_{2}, \mathrm{ZnCl}_{2}, \mathrm{MgCl}_{2}$, $\mathrm{HgCl}_{2}$ and $\mathrm{N}$-acetyl cysteine on LAAO activity for substartes with highest specificites. We observed only $\mathrm{ZnCl}_{2}, \mathrm{HgCl}_{2}$ and $\mathrm{N}$-acetyl cysteine showed significant inhibition for LAAO activity (Additional file 1A and 1B).

\section{P-I metalloproteinases and LAAO induce both necrosis and apoptosis in endothelial cells}

To understand toxicity of P-I metalloproteinases and LAAO, we performed MTT assays. Upon culturing fibroblasts for $24 \mathrm{~h}$, we observed that P-I metalloproteinases and LAAO induced approximately $20 \%$ and $20-30 \%$ cell death respectively. These proteins were more toxic to endothelial cells than fibroblasts and HepG2. P-I metalloproteinases induced cell death of nearly $40 \%$ whereas LAAO stimulated $50 \%$ cell death after $24 \mathrm{~h}$. This suggests that metalloproteinases and LAAO derived from Bothrops spp. possess cell specific effects (Additional file 2A, 2B and 2C).

Further, we performed flow cytometry analysis to distinguish apoptosis and necrosis by staining phosphatidylserine with annexin V. HUVECs were treated with P-I metalloproteinase and LAAO for $12 \mathrm{~h}$. The treatment on endothelial cells with both proteins showed a significant decrease in the viable cells and promoted large number of cells at late apoptotic phase of 
$16 \%$ and $31 \%$ in presence BmMP-1 and BaMP-1 respectively. Similarly, BmLAAO and BaLAAO induced apoptosis of $34 \%$ and $25 \%$ respectively. PI stained cells indicated necrosis of significant proportion of cells at 35\% (BmMP-1) and 36\% (BaMP-1) by P-I metalloproteinases and 42\% (BmLAAO) and 43\% (BaLAAO) by LAAO. These results indicated that P-I metalloproteinases and LAAO induced both necrosis and late apoptotic mode of cells death (Fig. 3A, Additional file 3B).

\section{P-I metalloproteinases and LAAO facilitated significant re-distribution of cells in cell cycle phases}

Further, we examined the influence of P-I metalloproteinases and LAAO on cell cycle. HUVECs were treated with P-I metalloproteinases and LAAO for $12 \mathrm{~h}$ and analysed by flow cytometry for PI staining. The endothelial cells treated with both the proteins rearranged the distribution in G0/G1, S and $\mathrm{G} 2 / \mathrm{M}$ phases. In comparison with control (42\%), treatment of BmMP-1 and BaMP-1 showed 53\% and 52\% cells in G0/G1 phase respectively. Similarly, we observed the significant increase in G0/G1 phase of $54 \%$ and $63 \%$ after treating with BmLAAO and BaLAAO respectively. We also observed a decrease in the accumulation of cells in the G2/M phase when compared to control indicating reduction in the mitotic cells. These results suggested that P-I metalloproteinases and LAAO arrested the cells G0/G1 (Fig. 3B) (Additional file 3A).

\section{P-I metalloproteinases and LAAO from Bothrops spp. inhibit angiogenesis}

We further tested the ability of P-I metalloproteinases and LAAO to modulate angiogenesis using in vitro (3D methylcellulose/ collagen) and in vivo (dorsal skin implantation) models. Endothelial cells were cultured in 3D collagen models in the presence or absence of different concentration of BmMP-1 and BaMP-1/BmLAAO and BaLAAO and assessed for their functional role in modulating angiogenesis. As a positive control bFGF was used, which showed robust induction in the sprout formation when compared to the control (Fig. 4A). We observed inhibition of sprouts from spheroids only when treated with P-I metalloproteinases at $2 \mu \mathrm{g} / \mathrm{mL}$ (Fig. 4B and 4D). However, the spheroids treated with a concentration of $0.5 \mu \mathrm{g} / \mathrm{mL}$ and 1 $\mu \mathrm{g} / \mathrm{mL}$ did not show any effect on inhibiting sprout formation. Further, LAAO at the concentrations of $10 \mathrm{ng} / \mathrm{mL}$ and $100 \mathrm{ng} / \mathrm{mL}$ inhibited sprout formation significantly. (Fig. 4C and 4E). To further validate the findings, we also performed matrigel assays. We observed re-arrangement of HUVECs on matrigel within 6 $\mathrm{h}$ upon treating with bFGF. However, P-I metalloproteinases $(0.2$ folds) and LAAO (0.5 folds) strongly inhibited the formation of tubes by HUVECs on Matrigel at the concentration of $2 \mu \mathrm{g} / \mathrm{mL}$ and $100 \mathrm{ng} / \mathrm{mL}$ respectively. While P-I metalloproteinases from both species inhibited/delayed formation of intact tubes, LAAO treatment was found to be more toxic to cells and changed the cellular phenotype (Fig. 5A and 5B).

We further investigated the effects of these proteins in vivo models using agarose plug assays in the mouse. Agarose was mixed with protein was placed under the subcutaneous space of mice and incubated for 5 days. Our in vivo data mirrored the results of in vitro analysis. We observed the densities of capillaries were reduced on the skin when treated with BmMP-1 and BaMP-1 $(5 \mu \mathrm{g} / \mathrm{mL})$ and BmLAAO and BaLAAO $(1 \mu \mathrm{g} / \mathrm{mL})$. These results indicated that P-I metalloproteinase and LAAO possess anti-angiogenic activities (Fig. 6A and 6B).
A

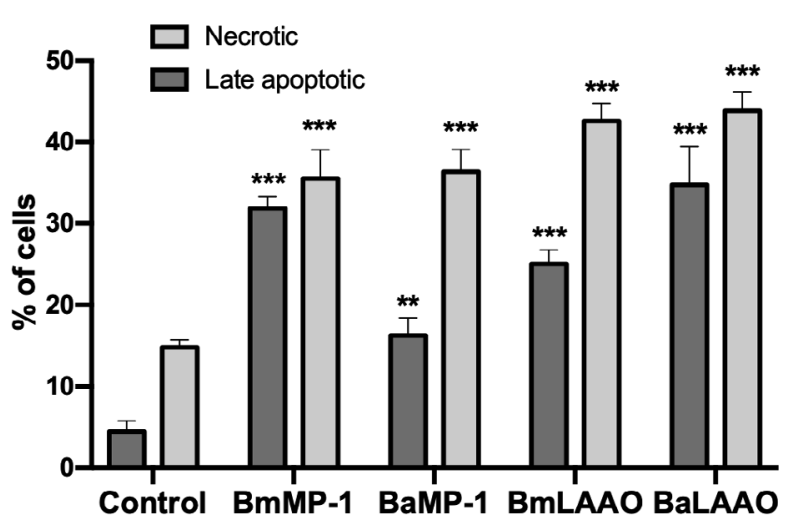

B

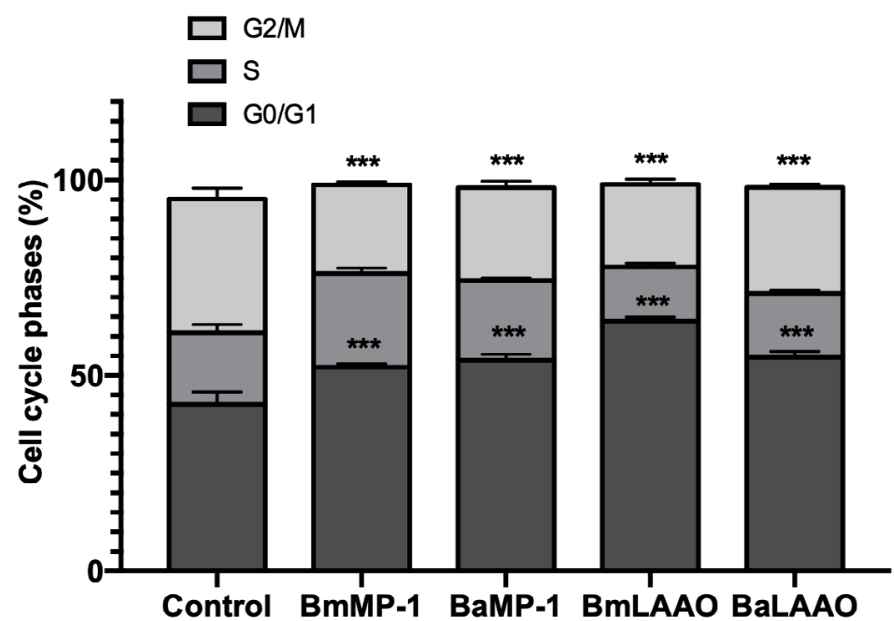

Figure 3. Influence of P-I metalloproteinases and LAAO on apoptosis and cell cycle. The endothelial cells were treated with BmMP-1 or BaMP-1 ( $2 \mu \mathrm{g} / \mathrm{mL})$ and BmLAAO or BaLAAO (100 ng/mL) and processed for flow cytometry analysis to determine (A) mode of cell death and (B) (re)distribution of cells into cell cycle phases. (A) Cells were stained with annexin $\vee$ conjugated with FITC and propidium iodide and analysed in a flow cytometer. Data are represented in percentage for necrotic and late apoptotic cells versus control. Statistical significance is represented by asterisk, $* * * p<0.001$ and $* * p<0.01$ versus control. (B) After treating cells as indicated above, they were fixed in ethanol and stained with PI and analysed by flow cytometry. Data are represented in percentage for G0/G1 (arrest/ preparation), S (DNA synthesis) G2/M (mitosis preparation) against control. Statistical significance is represented as asterisk **** $<0.001$. 
A

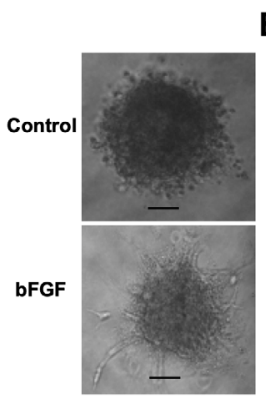

B $\quad 0.5 \mu \mathrm{g} / \mathrm{mL}$

$1 \mu \mathrm{g} / \mathrm{mL}$

$2 \mu \mathrm{g} / \mathrm{mL}$
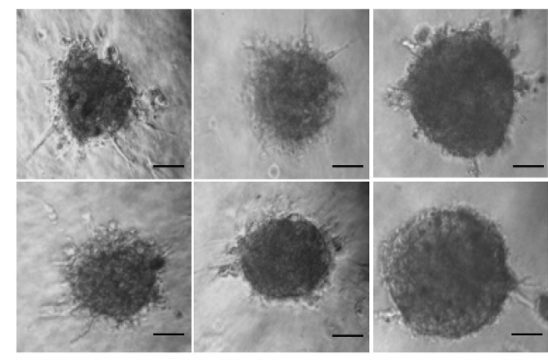

BmMP-1

$1 \mathrm{ng} / \mathrm{mL}$

$10 \mathrm{ng} / \mathrm{mL}$

$100 \mathrm{ng} / \mathrm{mL}$
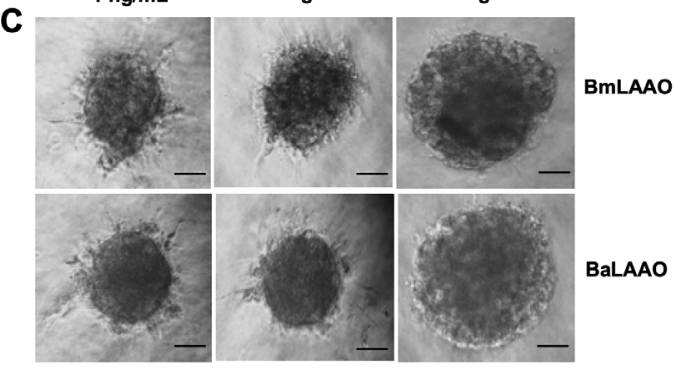

D

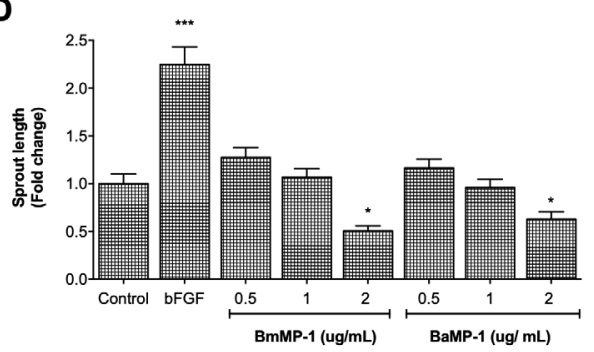

E

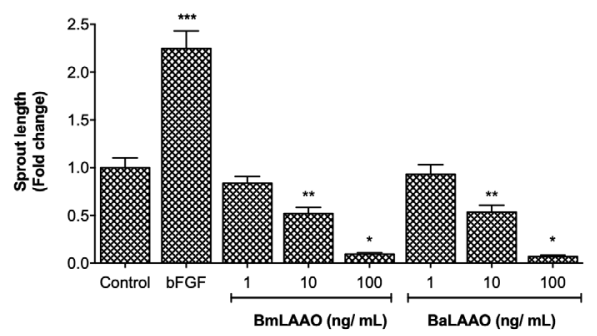

Figure 4. P-I metalloproteinases and LAAO inhibits endothelial sprouting. (A, B, C) Endothelial cells were cultured in collagen in the presence of either bFGF $(10 \mathrm{ng} / \mathrm{mL})$, or different concentrations of BmMP-1 or BaMP-1 $(0.5 \mu \mathrm{g} / \mathrm{mL}, 1 \mu \mathrm{g} / \mathrm{mL}$ and $2 \mu \mathrm{g} / \mathrm{mL})$ or BmLAAO or BaLAAO $(1 \mathrm{ng} / \mathrm{mL}, 10 \mathrm{ng} / \mathrm{mL}$ and $100 \mathrm{ng} / \mathrm{mL}) /$ for 24 hours and then were assessed for sprout outgrowth. Sprout length for each protein was compared to untreated control. Micrographs were captured in 10x magnification in an inverted microscope. (D) and (E) Graphical representation of modulation of angiogenesis is represented as fold change in sprout length and statistical significance is indicated as $* * * p<0.001, * * p<0.01$ and ${ }^{*} p<0.05$ versus control. Scale $=50 \mu \mathrm{m}$.

A

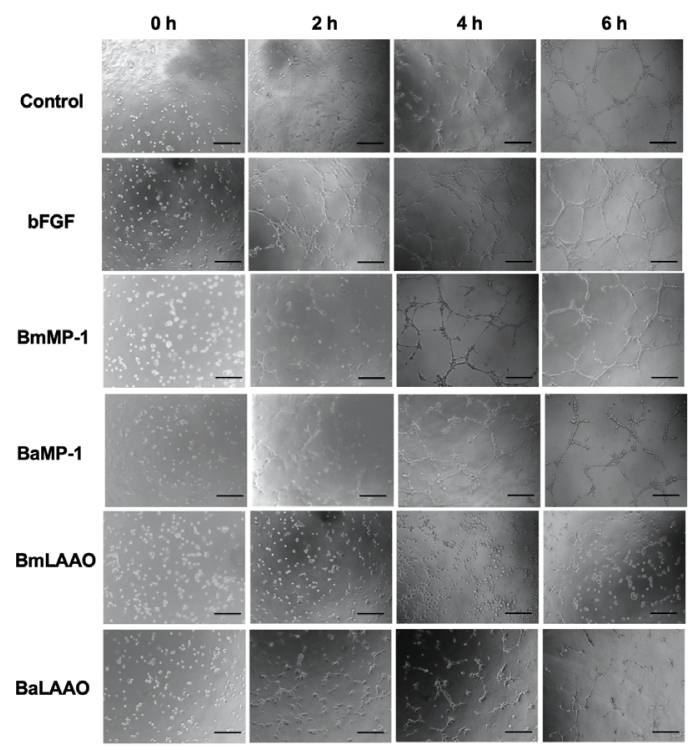

B

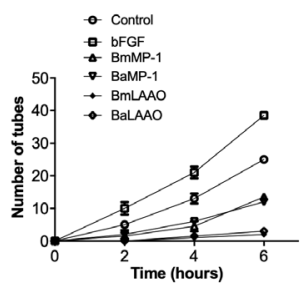

Figure 5. P-I metalloproteinases and LAAO inhibit endothelial tube formation. HUVECs on (A) Matrigel cushion were treated with BmMP-1 or BaMP-1 (2 $\mu$ g/mL)/ BmLAAO or BaLAAO $(100 \mathrm{ng} / \mathrm{mL}) / \mathrm{bFGF}(10 \mathrm{ng} / \mathrm{mL})$ and kinetics of tube formation was counted for every 2 hours. Micrographs were captured in 10× magnification in an inverted microscope. (B) Graphical representation of modulation of angiogenesis is represented as fold change in tube formation. Scale $=50 \mu m$. 
A
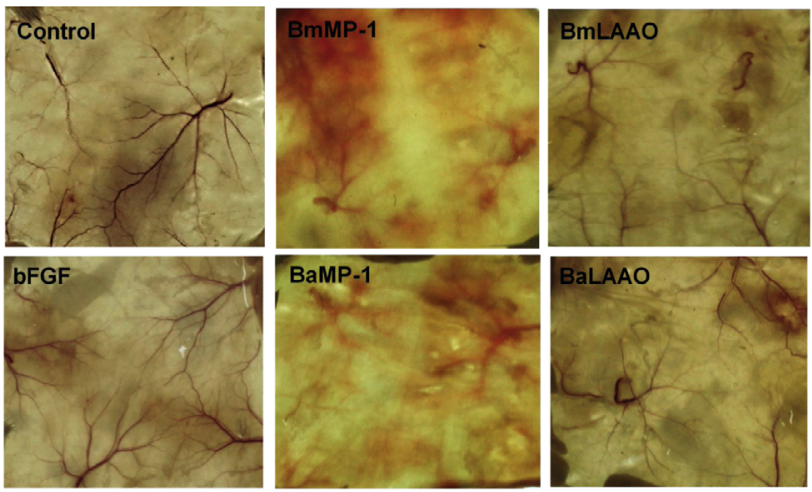

B

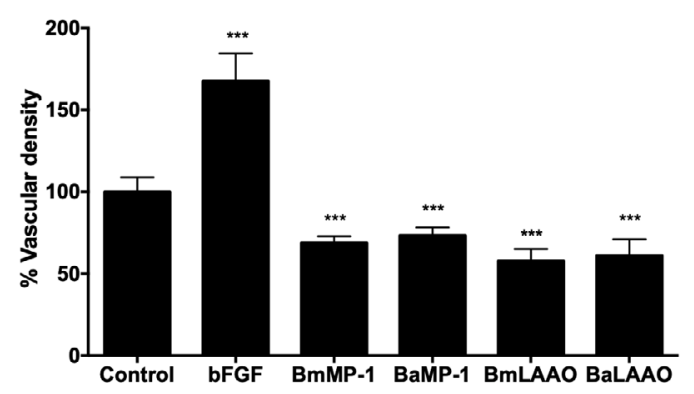

Figure 6. $\mathrm{P}-\mathrm{I}$ metalloproteinases and LAAO inhibit angiogenesis in vivo. (A) BmMP-1 or BaMP-1 (5 $\mu \mathrm{g} / \mathrm{mL})$ or BmLAAO or BaLAAO $(1 \mu \mathrm{g} / \mathrm{mL})$ or bFGF (100 ng/mL) or PBS embedded in agarose plugs were implanted into subcutaneous space of mice and observed for five days. Degradation of capillaries was observed on skin treated with both the proteins. (B) The percentage of vascular density was measured and compared to control. $* * * p<0.001$ versus control.

\section{Discussion}

Mounting evidences have demonstrated functional characterization and therapeutic utility of metalloproteinases and LAAO from various snake venom. P-I metalloproteinases are the simple and smallest metalloproteinase protein, which exhibits the molecular mass of $20-30 \mathrm{kDa}$ and contains only metalloproteinase domain [7]. These proteins harbour conserved zinc binding sequence along with Methionine-turn motifs [20]. Earlier studies have demonstrated isolation and characterization of P-I metalloproteinases from Bothrops spp. Patiño et al. [43] isolated P-I metalloproteinases with a molecular mass of $23.3 \mathrm{kDa}$ from $B$. atrox by ion-exchange and affinity chromatography [43]. Similarly, P-I metalloproteinases isolated from B. moojeni by a combination of size exclusion, ion-exchange and affinity chromatography displayed molecular mass of $22.6 \mathrm{kDa}$ protein [19]. In our present study, the P-I metalloproteinases isolated upon combining size exclusion and ion-exchange chromatography from B. moojeni and B. atrox showed molecular mass of $\sim 25$ $\mathrm{kDa}$ as observed in SDS PAGE.

P-I metalloproteinases were extensively characterized by their catalytic activity on casein and fibrinogen. P-I metalloproteinases (BaP1) isolated from B. asper degraded the casein at 17.8 units/ mg protein [44]. P-I metalloproteinases (Bmoo FIBMP-I) from the venom of $B$. moojeni exhibited $\mathrm{pH}$ dependent catalytic activity on azocasein with $\mathrm{K}_{\mathrm{m}}=14.59 \mathrm{mg} / \mathrm{mL} \pm 4.610$ and $\mathrm{V}_{\max }$ $=0.4596 \mathrm{Uh}^{-1} \mathrm{nmol}^{-1} \pm 0.1031$ [45]. Kayano et al. [40] isolated
P-I metalloproteinases from B. brazili that showed activity at different concentrations and were inhibited by EDTA and DTT, but not by PMSF. Metalloproteinases isolated from Lachesis muta rhombeata snake venom showed maximum activity on azocasein at pH 7.0 - 9.0 and were also inhibited by EDTA but no effect with PMSF [46]. P-I metalloproteinases isolated from B. moojeni [47, 48], B. asper [49] and B. atrox [43] cleaved Aa chain of fibrinogen. Further, proteomic analysis of Bothrops snake venom demonstrated an intense gelatinolytic activity around $25 \mathrm{kDa}$ region $[48,50]$. In agreement with previous studies and as summarized in Table 1, in our study P-I metalloproteinases purified from Bothrops spp. also showed significant ability to digest casein and possessed gelatinolytic and fibrinogenolytic activity.

The class of LAAO molecules was first identified by Zeller and Maritiz (1945) from the venom of Vipera aspis [51]. Singer and Kearney [52] first isolated LAAO from Agkistrodon piscivorus venom and the crystal structure of LAAO from Crotalus adamanteus venom was obtained by Wellner and Meister in 1960s [53]. The molecular weight of LAAO as reported in earlier studies ranged from $38 \mathrm{kDa}$ to $67 \mathrm{kDa}$. Earlier studies have purified and performed biochemical characterization of LAAO proteins. LAAO isolated from B. atrox by Costal-Oliveira et al. [32] by three chromatographic process molecular size exclusion, ion-exchange and affinity chromatography showed molecular mass of $57 \mathrm{kDa}$ protein. Further, Stábeli et al. [54] isolated LAAO $(64.8 \mathrm{kDa})$ from B. moojeni by ion-exchange chromatography 
and phenyl-sepharose chromatography. The LAAO isolated from both $B$. moojeni and B. atrox in the present study exhibited molecular mass of $\sim 58 \mathrm{kDa}$ protein as observed on SDS PAGE which is in the agreement with the previous studies $[32,54,55]$.

LAAO isolated from various snake venom for over the years have demonstrated differential activity towards L-amino acids. LAAO isolated from $B$. atrox showing high catalytic activity against $\mathrm{M}>\mathrm{L}>\mathrm{F}>\mathrm{W}>\mathrm{Y}>\mathrm{I}$ at a concentration of $15 \mu \mathrm{g} / \mathrm{mL}$ [56]. Further, LAAO (Balt-LAAO-1) from B. alternatus showed catalytic activity only towards $\mathrm{P}>\mathrm{T}>\mathrm{M}>\mathrm{L}$ [57], but LAAO (BpirLAAO-1) isolated from $B$. pirajai at a concentration of $2 \mathrm{U}$ exhibited catalytic activity on hydrophobic and long chain amino acids $\mathrm{F}>\mathrm{Y}>\mathrm{W}>\mathrm{L}>\mathrm{M}>\mathrm{I}>\mathrm{V}>\mathrm{H}$ [58]. Although, the protein homology of the LAAO from Bothrops spp. ranged from $80 \%$ to $90 \%$, activity of the proteins on amino acids varied as observed in earlier studies. This suggested that the structural makeup of LAAO protein might impact activity and substrate specificity.

The evolution of snake venom molecules over the millions of years facilitated in capturing the prey and defence from predators. Majority of the snake venoms have been well characterized and comprises mixture of distinct array of proteins and peptides results in varied toxicological and pharmacologically effects [59]. The main pharmacological effects of snake venom are broadly classified as hemotoxic, cytotoxic and neurotoxic [60] caused by major proteins, either alone or combination of LAAO, phospholipase $A_{2}$, snake venom serine proteinases, SVMPs and 3 finger toxins occurs during envenomation. The metalloproteinases in venom causes local and systematic hemorrhage, affecting the blood vessels [18]. These hemorrhagic enzymes may directly breakdown the basement components and their key peptide bonds, affecting the endothelial cell interaction between the basement membrane predominantly type IV collagen and perlecan [61]. In vivo, this may facilitate morphological and functional alteration of endothelial cells affecting extravasation thereby forming gaps between the endothelial cells leading to divergent fluid shear stress [62]. LAAO in the venom majorly causes hemorrahge and edema promoting the degradation of matrix proteins of endothelial cells and increasing the vascular permeability which may fluid leakage from the capillary vessels to interstitial space of tissues [57]. LAAO causes cytotoxicity on endothelial cells by necrosis and apoptosis. Necrosis is caused by direct action of the protein or catabolic products of plasma membrane which promotes the degeneration of the cells and apoptosis is caused by ROS production [4]. Taken together, these findings suggest that during envenomation, snake venom components induce cytotoxic effects on various cell types including endothelial cells, neuronal cells, myoblasts and epithelial cells and might contribute to delayed tissue regeneration and associated wound healing.

Snake venom proteins and peptides have been extensively explored for their properties to target pathological angiogenesis. The previous studies have demonstrated serine proteinases to facilitate significant neovascularization via PI3K/Akt pathway [39]. Similarly, proteins inhibiting angiogenesis are of pharmaceutical interest particularly to inhibit to neovascularization in pathological conditions associated with excessive angiogenesis such as in tumours, diabetic retinopathy and arthritis. Hence, in the present study, we have demonstrated that P-I metalloproteinases from B. atrox and B. moojeni and LAAO from B. moojeni and B. atrox showed anti-angiogenic properties.

SVMPs have been demonstrated as versatile toxins, which target hemostatic system such as clotting proteins, endothelial cells, basement membrane proteins and platelets [63]. Earlier studies have demonstrated that SVMP activated apoptotic pathways. A metalloproteinase (jararhagin) isolated from $B$. jararaca induced apoptosis of endothelial cells via anoikis [24,64]. The catalytic activity of the protein is reported to affect the cytoskeleton dynamics such as cell retraction, followed by alteration of actin network, reduced association of focal adhesion kinase (FAK) to actin and also indicated to interfere with the focal adhesion contacts of tyrosine phosphorylated proteins. It was observed that the morphological changes on endothelial cells resulted in pro-caspase- 3 activation leading to apoptosis and alteration in the ratio between $\mathrm{Bax} / \mathrm{Bcl}-\mathrm{xL}$ [64]. BaP1 (metalloproteinase-1) from B. asper venom [51,65] induced apoptosis in endothelial cells via activated pro-caspase 8 and c-FLIPL up-regulation [66]. However, jararhagin [64] and halysase [67] induced apoptosis through Bax and Bcl-xL expression, leading to activation of the extrinsic pathway [66]. Further, graminelysin (metalloproteinase-1 isolated from Trimeresurus gramineus venom) [68] triggered apoptosis by its catalytic activity on endothelial cells which occurred before cell detachment, subsequently activating the caspase- 3 and the reduction in the ratio of Bcl-2/Bax [69]. The proteins associated with adherens junction were cleaved with a significant reduction in the levels of $\alpha$-catenin, which disrupted the association with the actin cytoskeleton and interfere with the endothelial cell extracellular signals [69]. BpMP-II (P-I metalloproteinases) isolated from B. pauloensis influenced adhesive and tube forming properties of rat thymic endothelial cells suggesting, anti-angiogenic property of SVMPs [70]. Corroborating previous studies, P-I metalloproteinases from both B. atrox and B. moojeni induced apoptosis in endothelial cells. However, the concentrations of these proteins used in our study was significantly lower $(2 \mu \mathrm{g} / \mathrm{mL})$ against earlier studies which ranged from $20-200 \mu \mathrm{g} / \mathrm{mL}$ [60-70]. Interestingly, we also observed that P-I-metalloproteinase-induced apoptosis was more intense in HUVEC than in fibroblasts and HepG2.

LAAO in the venom, majorly responsible for apoptosis in endothelial cells by producing $\mathrm{H}_{2} \mathrm{O}_{2}$ and inducing caspasemediated apoptosis driven by ROS, activating caspase- 3 and caspase-9 [71,72]. Apoxin I (LAAO from Crotalus atrox), showed apoptotic effect on HUVECs, A2780, HL-60 and NK-3 (rat endothelial cells) by inducing the condensation and fragmentation of DNA [72]. Wei et al. [73] isolated LAAO (BFLAAO) from the venom of Bungarus fasciatus, inhibited the growth and induced the apoptosis in HUVECs by dose depended manner with an IC50 value of $2.8 \mathrm{mg} / \mathrm{L}$. LAAO-II isolated from $B$. jararacassu significantly reduced the viability and survival 
and further, induced DNA damage in human endothelial cells upon increasing ROS levels [30]. Concentrations of LAAO used in our study were also lower than that of earlier studies [30,71-73] and similarly to P-I metalloproteinases, LAAO induced cytotoxic effects were more prominent in endothelial cells than fibroblasts.

\section{Conclusion}

In the present study, we have isolated P-I metalloproteinases and LAAO from B. moojeni and B. atrox, and extensively characterized them based on their enzymatic activities. P-I metalloproteinases and LAAO arrested the cells in G0/G1 phase of cell cycle and also led to cytotoxic activity in endothelial cells by inducing necrosis/late apoptotic mode of cell death. We further demonstrated that both proteins were able to distress the endothelial cells in vitro and significantly inhibited the growth of the capillaries in vivo. Our findings suggest that metalloproteinases and LAAO from venoms cause cytotoxicity to endothelial cells and might inhibit tissue regeneration and subsequently delay wound healing. Such anti-vascular effects of these proteins can be further explored to design therapeutic strategies to inhibit angiogenesis. However, further studies are essential to investigate the underlying molecular mechanisms and explore the therapeutic implications of these proteins.

\section{Acknowledgments}

The authors would like to acknowledge TIFAC-CORE, Government of India and Manipal Academy of Higher Education for the infrastructure. Thanks are also due to Dr. K. P. Guruprasad for flow cytometry analysis and Ms. Jyothi Nayak, Mr. Gangadhar and Mr. Manoj for the technical assistance.

\section{Availability of data and materials}

All data generated or analysed during this study are included in this article.

\section{Funding}

The project was funded by the Department of Biotechnology, Government of India under Indo-Brazil joint call for proposal (DBT/In- Bz/2013-16/08), CAPES Toxinologia (1214/2011), FAPESP (2015/13765-0) and MCTI/CNPq/DBT 401388/2013-1.

\section{Competing interests}

The authors declare that they have no competing interests.

\section{Authors' contributions}

$\mathrm{SKB}, \mathrm{SV}$ and MAC were responsible for generating and analysing data. SKB, MBJ and RKA analysed data and wrote the manuscript. RNJ and SGB participated in the study. KS conceived and supervised the study. All authors read and approved the final manuscript.

\section{Ethics approval}

The present study was approved by the Institutional Animal Ethics Committee (IAEC), Manipal Academy of Higher Education, Manipal (IAEC/KMC/48/2015). Animal handling was carried out in accordance with the standard guidelines of the committee for the purpose of control and supervision on experiments on animals (CPCSEA), Government of India.

\section{Consent for publication}

Not applicable.

\section{Supplementary material}

The following online material is available for this article:

Additional file 1. Inhibitory activity of LAAO. The effect of inhibitors on (A) BmLAAO or (B) BaLAAO activity was measured in the presence or absence of divalent metals $\mathrm{CaCl}_{2}$, $\mathrm{MgCl}_{2}, \mathrm{ZnCl}_{2}$ and $\mathrm{HgCl}_{2}$ (all $10 \mathrm{mM}$ ) and amino acid derivative $\mathrm{N}$-acetyl cysteine (NAC) (5 mM). Data are represented as percentage of untreated control and statistical significance is indicated by asterisk ${ }^{* * *} \mathrm{p}<0.001$.

Additional file 2. Influence of P-I metalloproteinases and LAAO from Bothrops venom on cell survival. (A) and (B) Endothelial cells, (C) HepgG2 and fibroblast cells were treated with either BmMP-1 or BaMP-1 or BmLAAO or BaLAAO and mitomycin for 24 hours in normal culture conditions and cells were processed for MTT assay. Data are represented as percentage of untreated control cells versus treated in each cell type. Statistical significance was denoted by asterisk. ${ }^{* *} \mathrm{p}<0.001$, ${ }^{* *} \mathrm{p}<0.01,{ }^{*} \mathrm{p}<0.05$ versus control.

Additional file 3. Influence of P-I metalloproteinases and LAAO on apoptosis and cell cycle. The endothelial cells were treated with BmMP-1 or BaMP-1 $(2 \mu \mathrm{g} / \mathrm{mL})$ and BmLAAO or BaLAAO (100 ng/mL) and processed for flow cytometry analysis. (A) Cells were stained with annexin V conjugated with FITC and propidium iodide and analysed in a flow cytometer. (B) After treating cells as indicated above, they were fixed in ethanol and stained with PI and analysed by flow cytometry.

\section{References}

1. Georgieva D, Arni RK, Betzel C. Proteome analysis of snake venom toxins: pharmacological insights. Expert Rev Proteomics. 2008 Dec;5(6):787-97.

2. Lewis RJ, Garcia ML. Therapeutic potential of venom peptides. Nat Rev Drug Discov. 2003 Oct;2(10):790-802.

3. Fenwick AM, Gutberlet RL, Evans JA, Parkinson CL. Morphological and molecular evidence for phylogeny and classification of South American pitvipers, genera Bothrops, Bothriopsis, and Bothrocophias (serpentes: Viperidae). Zool J Linnean Soc. 2009;156(3):617-40.

4. Morais ICO, Pereira GJS, Orzáez M, Jorge RJB, Bincoletto C, Toyama MH, Monteiro HAS, Smaili SS, Pérez-Payá E, Martins AMC. L-aminoacid oxidase from Bothrops leucurus venom induces nephrotoxicity via apoptosis and necrosis. PLoS One. 2015 Jul 20;10(7):e0132569.

5. Rezende NA, Amaral CF, Bambirra EA, Lachatt JJ, Coimbra TM. Functional and histopathological renal changes induced in rats by Bothrops jararaca venom. Braz J Med Biol Res. 1989;22(3):407-16. 
6. Senise LV, Yamashita KM, Santoro ML. Bothrops jararaca envenomation: pathogenesis of hemostatic disturbances and intravascular hemolysis. Exp Biol Med (Maywood). 2015 Nov;240(11):1528-36.

7. Markland FS Jr, Swenson S. Snake venom metalloproteinases. Toxicon. 2013 Feb;62:3-18.

8. Matsui T, Fujimura Y, Titani K. Snake venom proteases affecting hemostasis and thrombosis. Biochim Biophys Acta. 2000 Mar 7;1477(1-2):146-56.

9. Gutiérrez JM, Rucavado A. Snake venom metalloproteinases: their role in the pathogenesis of local tissue damage. Biochimie. 2000 SepOct;82(9-10):841-50.

10. Fox JW, Serrano SMT. Structural considerations of the snake venom metalloproteinases, key members of the $\mathrm{M} 12$ reprolysin family of metalloproteinases. Toxicon. 2005 Jun 15;45(8):969-85.

11. Olaoba OT, Dos Santos PK, Selistre-de-Araujo HS, de Souza DHF. Snake venom metalloproteinases (SVMPs): a structure-function update. Toxicon X. 2020 Jul 21;7: 100052

12. Escalante T, Rucavado A, Fox JW, Gutiérrez JM. Key events in microvascular damage induced by snake venom hemorrhagic metalloproteinases. J Proteom. 2011 Aug 24;74(9):1781-94.

13. Hernández R, Cabalceta C, Saravia-Otten P, Chaves A, Gutiérrez JM, Rucavado A. Poor regenerative outcome after skeletal muscle necrosis induced by Bothrops asper venom: alterations in microvasculature and nerves. PLoS One. 2011;6(5):e19834.

14. Freitas-de-Sousa LA, Colombini M, Lopes-Ferreira M, Serrano SMT, Moura-da-Silva AM. Insights into the mechanisms involved in strong hemorrhage and dermonecrosis induced by atroxlysin-la, a PI-class snake venom metalloproteinase. Toxins (Basel). 2017 Aug 2;9(8):239.

15. Fernandes CM, Pereira Teixeira CF, Leite ACRM, Gutiérrez JM, Rocha FAC. The snake venom metalloproteinase BaP1 induces joint hypernociception through TNF-alpha and PGE2-dependent mechanisms. Br J Pharmacol. 2007 Aug;151(8):1254-61.

16. Almeida MT, Freitas-de-Sousa LA, Colombini M, Gimenes SNC, Kitano ES, Faquim-Mauro EL, Serrano SMT, Moura-da-Silva AM. Inflammatory reaction induced by two metalloproteinases isolated from Bothrops atrox venom and by fragments generated from the hydrolysis of basement membrane components. Toxins (Basel). 2020 Feb 2;12(2):96.

17. Ferreira BA, Deconte SR, de Moura FBR, Tomiosso TC, Clissa PB, Andrade $\mathrm{SP}$, Araújo FA. Inflammation, angiogenesis and fibrogenesis are differentially modulated by distinct domains of the snake venom metalloproteinase jararhagin. Int J Biol Macromol. 2018 Nov;119:1179-87.

18. Sanchez EF, Flores-Ortiz RJ, Alvarenga VG, Eble JA. Direct fibrinolytic snake venom metalloproteinases affecting hemostasis: structural, biochemical features and therapeutic potential. Toxins (Basel). 2017 Dec 5;9(12):392.

19. Okamoto DN, Kondo MY, Oliveira LCG, Honorato RV, Zanphorlin LM Coronado MA, Araújo MS, da Motta G, Veronez CL, Andrade SS, Oliveira PSL, Arni RK, Cintra ACO, Sampaio SV, Juliano MA, Juliano L, Murakami MT, Gouvea IE. PI class metalloproteinase from Bothrops moojeni venom is a post-proline cleaving peptidase with kininogenase activity: insights into substrate selectivity and kinetic behavior. Biochim Biophys Acta. 2014 Mar;1844(3):545-52.

20. Herrera C, Escalante T, Voisin MB, Rucavado A, Morazán D, Macêdo JKA, Calvete JJ, Sanz L, Nourshargh S, Gutiérrez JM, Fox JW. Tissue localization and extracellular matrix degradation by PI, PII and PIII snake venom metalloproteinases: clues on the mechanisms of venom-induced hemorrhage. PLoS Negl Trop Dis. 2015 Apr 24;9(4):e0003731.

21. Torres-Huaco FD, Maruñak S, Teibler P, Bustillo S, de Pérez OA, Leiva LC, Ponce-Soto LA, Marangoni S. Local and systemic effects of BtaMP-1, a new weakly hemorrhagic snake venom metalloproteinase purified from Bothriopsis taeniata snake venom. Int J Biol Macromol. 2019 Dec 1;141:1044-54.

22. da Silva IRF, Lorenzetti R, Rennó AL, Baldissera L Jr, Zelanis A, Serrano SMT, Hyslop S. BJ-PI2, a non-hemorrhagic metalloproteinase from Bothrops jararaca snake venom. Biochim Biophys Acta. 2012 Nov;1820(11):1809-21.

23. Sanchez EF, Richardson M, Gremski LH, Veiga SS, Yarleque A, Niland S, Lima AM, Estevao-Costa MI, Eble JÁ. A novel fibrinolytic metalloproteinase, barnettlysin-I from Bothrops barnetti (Barnett's pitviper) snake venom with anti-platelet properties. Biochim Biophys Acta. 2016 Mar;1860(3):542-56.
24. Schattner M, Fritzen M, Ventura JS, de Albuquerque Modesto JC, Pozner RG, Moura-da-Silva AM, Chudzinski-Tavassi AM. The snake venom metalloproteases berythractivase and jararhagin activate endothelial cells. Biol Chem. 2005 Apr;386(4):369-74.

25. Du XY, Clemetson KJ. Snake venom L-amino acid oxidases. Toxicon. 2002 Jun;40(6):659-65.

26. Braga MDM, Martins AMC, Amora DN, de Menezes DB, Toyama MH, Toyama DO, Marangoni S, Alves CD, Barbosa PSF, Alves RS, Fonteles MC, Monteiro HSA. Purification and biological effects of $L$-amino acid oxidase isolated from Bothrops insularis venom. Toxicon. 2008 Feb;51(2):199-207.

27. Costa TR, Burin SM, Menaldo DL, de Castro FA, Sampaio SV. Snake venom L-amino acid oxidases: an overview on their antitumor effects. J Venom Anim Toxins incl Trop Dis. 2014 Juhn 2;20(1):23.

28. Guo C, Liu S, Yao Y, Zhang Q, Sun MZ. Past decade study of snake venom L-amino acid oxidase. Toxicon. 2012 Sep 1;60(3):302-11.

29. Ribeiro PH, Zuliani JP, Fernandes CFC, Calderon LA, Stábeli RG, Nomizo $A$, Soares AM. Mechanism of the cytotoxic effect of $L$-amino acid oxidase isolated from Bothrops alternatus snake venom. Int J Biol Macromol. 2016 Nov;92:329-37.

30. Machado ART, Aissa AF, Ribeiro DL, Costa TR, Ferreira RS Jr, Sampaio SV, Antunes LMG. Cytotoxic, genotoxic, and oxidative stress-inducing effect of an L-amino acid oxidase isolated from Bothrops jararacussu venom in a co-culture model of HepG2 and HUVEC cells. Int J Biol Macromol. 2019 Apr 15;127:425-32.

31. Heleno MAG, de Carvalho JE, Nowill A, Ponce-Soto LA. Cytotoxic activity of a new isoform L-amino acid oxidase (Balt-LAAO-II) from Bothrops alternatus (Urutu) snake venom in human leukemic HL60 cells. bioRxiv. 2020.

32. Costal-Oliveira F, Stransky S, Guerra-Duarte C, de Souza DLN, Vivas-Ruiz DE, Yarlequé A, Sanchez EF, Chávez-Olórtegui C, Braga VM. L-amino acid oxidase from Bothrops atrox snake venom triggers autophagy, apoptosis and necrosis in normal human keratinocytes. Sci Rep. 2019 Jan 28;9(1):1-14.

33. Imlay JA. Pathways of oxidative damage. Annu Rev Microbiol. 2003;57(1):395-418.

34. Okubo BM, Silva ON, Migliolo L, Gomes DG, Porto WF, Batista CL, Ramos CS, Holanda HHS, Dias SC. Evaluation of an antimicrobial L-amino acid oxidase and peptide derivatives from Bothropoides mattogrosensis pitviper venom. PLoS One. 2012;7(3):e33639.

35. de Vieira Santos MM, Sant'Ana CD, Giglio JR, da Silva RJ, Sampaio SV, Soares AM, Fecchio D. Antitumoural effect of an L-amino acid oxidase isolated from Bothrops jararaca snake venom. Basic Clin Pharmacol. 2008 Jun;102(6):533-42.

36. Folkman J. Angiogenesis in cancer, vascular, rheumatoid and other disease Nat Med.1995 Jan;1(1):27-31.

37. Teleanu RI, Chircov C, Grumezescu AM, Teleanu DM. Tumor angiogenesis and anti-angiogenic strategies for cancer treatment. J Clin Med. 2020;9(1):84.

38. Dhananjaya BL, Sivashankari PR. Snake venom derived molecules in tumor angiogenesis and its application in cancer therapy; an overview. Curr Top Med Chem. 2015;15(7):649-57

39. Bhat SK, Joshi MB, Ullah A, Masood R, Biligiri SG, Arni RK, Satyamoorthy $K$. Serine proteinases from Bothrops snake venom activates PI3K/Akt mediated angiogenesis. Toxicon. 2016 Dec 15;124:63-72.

40. Kayano AM, Simões-Silva R, Medeiros PSM, Maltarollo VG, Honorio KM, Oliveira E, Albericio F, da Silva SL, Aguiar ACC, Krettli AU, Fernandes CFC, Zuliani JP, Calderon LA, Stábeli R, Soares AM. BbMP-1, a new metalloproteinase isolated from Bothrops brazili snake venom with in vitro antiplasmodial properties. Toxicon. 2015 Nov;106:30-41.

41. Zaqueo KD, Kayano AM, Simões-Silva R, Moreira-Dill LS, Fernandes CFC, Fuly AL, Maltarollo VG, Honório KM, da Silva SL, Acosta G, Caballol MAO, de Oliveira E, Albericio F, Calderon LA, Soares AM, Stábeli RG. Isolation and biochemical characterization of a new thrombin-like serine protease from Bothrops pirajai snake venom. Biomed Res Int. 2014;2014: 595186.

42. Li ZY, Yu TF, Lian EC. Purification and characterization of L-amino acid oxidase from king cobra (Ophiophagus hannah) venom and its effects on human platelet aggregation. Toxicon. 1994 Nov;32(11):1349-58. 
43. Patiño AC, Pereañez JA, Núñez V, Benjumea DM, Fernandez M, Rucavado A, Sanz L, Calvete JJ. Isolation and biological characterization of Batx-I, a weak hemorrhagic and fibrinogenolytic PI metalloproteinase from colombian Bothrops atrox venom. Toxicon. 2010 Nov;56(6):936-43.

44. Mascelli MA, Kirby EP. Proteolytic studies on the structure of bovine von Willebrand factor. Biochemistry. 1988 Feb 23;27(4):1274-84.

45. Torres FS, Rates B, Gomes MTR, Salas CE, Pimenta AMC, Oliveira F, Santoro MM, de Lima ME. Bmoo FIBMP-I: a new fibrinogenolytic metalloproteinase from Bothrops moojeni snake venom. ISRN Toxicol. 2012 Nov 4;2012: 673941.

46. Cordeiro FA, Coutinho BM, Wiezel GA, Bordon KCF, Bregge-Silva C, RosaGarzon NG, Cabral H, Ueberheide B, Arantes EC. Purification and enzymatic characterization of a novel metalloprotease from Lachesis muta rhombeata snake venom. J Venom Anim Toxins incl Trop Dis. 2018 Nov 22;24:32.

47. Bernardes CP, Santos-Filho NA, Costa TR, Gomes MSR, Torres FS, Costa J, Borges MH, Richardson M, dos Santos DM, de Castro Pimenta AM, Homsi-Brandeburgo MI, Soares AM, de Oliveira F. Isolation and structural characterization of a new fibrin(ogen)olytic metalloproteinase from Bothrops moojeni snake venom. Toxicon. 2008 Mar 15;51(4):574-84.

48. Salvador GHM, Borges RJ, Eulálio MMC, Dos Santos LD, Fontes MRM. Biochemical, pharmacological and structural characterization of BmooMP-I, a new P-I metalloproteinase from Bothrops moojeni venom. Biochimie. 2020 Dec;179:54-64

49. Gutiérrez JM, Romero M, Díaz C, Borkow G, Ovadia M. Isolation and characterization of a metalloproteinase with weak hemorrhagic activity from the venom of the snake Bothrops asper (terciopelo). Toxicon. 1995 Jan;33(1):19-29.

50. Terra RMS, Pinto AFM, Guimaraes JA, Fox JW. Proteomic profiling of snake venom metalloproteinases (SVMPs): insights into venom induced pathology. Toxicon. 2009 Nov;54(6):836-44.

51. Zeller EA, Maritz A. Über eine neue I-Aminosäure-oxydase (Ophio-Iaminosäure-oxydase). 2. Mitteilung, Helv Chim Acta. 1945;28(1):365-79.

52. Singer TP, Kearney EB. The L-amino acid oxidases of snake venom. II. Isolation and characterization of homogeneous L-amino acid oxidase. Arch Biochem. 1950 Nov;29(1):190-209.

53. Wellner D, Meister A. Studies on the mechanism of action of L-amino acid oxidase. J Biol Chem. 1961 Aug;236:2357-64.

54. Stábeli RG, Sant'Ana CD, Ribeiro PH, Costa TR, Ticli FK, Pires MG, Nomizo A, Albuquerque S, Malta-Neto NR, Marins M, Sampaio SV, Soares AM. Cytotoxic L-amino acid oxidase from Bothrops moojeni: biochemical and functional characterization. Int J Biol Macromol. 2007 Jul 1;41(2):132-40.

55. Burin SM, Cacemiro MD, Cominal JG, Grandis RA, Machado ART, Donaires FS, Cintra ACO, Ambrosio L, Antunes LMG, Sampaio SV, de Castro FA. Bothrops moojeni L-amino acid oxidase induces apoptosis and epigenetic modulation on Bcr-Abl+ cells. J Venom Anim Toxins incl Trop Dis. 2020 Dec 14;26:e20200123.

56. Alves RM, Antonucci GA, Paiva HH, Cintra ACO, Franco JJ, MendonçaFranqueiro EP, Dorta DJ, Giglio JR, Rosa JC, Fuly AL, Dias-Baruffi M, Soares AM, Sampaio SV. Evidence of caspase-mediated apoptosis induced by L-amino acid oxidase isolated from Bothrops atrox snake venom. Comp Biochem Physiol A Mol Integr Physiol. 2008 Dec;151(4):542-50.

57. Stábeli RG, Marcussi S, Carlos GB, Pietro RCLR, Selistre-de-Araújo HS, Giglio JR, Oliveira EB, Soares AM. Platelet aggregation and antibacterial effects of an L-amino acid oxidase purified from Bothrops alternatus snake venom. Bioorg Med Chem. 2004 Jun 1;12(11):2881-6.

58. Izidoro LFM, Ribeiro MC, Souza GRL, Sant'Ana CD, Hamaguchi A, Homsi-Brandeburgo MI, Goulart LR, Beleboni RO, Nomizo A, Sampaio SV, Soares AM, Rodrigues VM. Biochemical and functional characterization of an L-amino acid oxidase isolated from Bothrops pirajai snake venom. Bioorg Med Chem. 2006 Oct 15;14(20):7034-43.

59. Zhang Y. Why do we study animal toxins?. Dongwuxue Yanjiu. 2015 Jul 18;36(4):183-222.

60. Fatima L, Fatah C. Pathophysiological and pharmacological effects of snake venom components: molecular targets. J Clin Toxicol. 2014;4(190):2161-0495.

61. Escalante T, Ortiz N, Rucavado A, Sanchez EF, Richardson M, Fox JW, Gutiérrez JM. Role of collagens and perlecan in microvascular stability: exploring the mechanism of capillary vessel damage by snake venom metalloproteinases. PloS One. 2011;6(12):e28017.
62. Gutiérrez JM, Escalante T, Rucavado A, Herrera C. Hemorrhage caused by snake venom metalloproteinases: a journey of discovery and understanding. Toxins (Basel). 2016 Mar 26;8(4):93.

63. Moura-da-Silva AM, Furlan MS, Caporrino MC, Grego KF, Portes-Junior JA, Clissa PB, Valente RH, Magalhães GS. Diversity of metalloproteinases in Bothrops neuwiedi snake venom transcripts: evidences for recombination between different classes of SVMPs. BMC Genet. 2011 Nov 1;12(1):94.

64. Tanjoni I, Weinlich R, Della-Casa MS, Clissa PB, Saldanha-Gama RF, de Freitas MS, Barja-Fidalgo C, Amarante-Mendes GP, Moura-da-Silva AM. Jararhagin, a snake venom metalloproteinase, induces a specialized form of apoptosis (anoikis) selective to endothelial cells. Apoptosis. 2005 Aug;10(4):851-61.

65. Watanabe L, Shannon JD, Valente RH, Rucavado A, Alape-Girón A, Kamiguti AS, Theakston RDG, Fox JW, Gutiérrez JM, Arni RK. Amino acid sequence and crystal structure of BaP1, a metalloproteinase from Bothrops asper snake venom that exerts multiple tissue-damaging activities. Protein Sci. 2003 Oct;12(10):2273-81.

66. Díaz C, Valverde L, Brenes O, Rucavado A, Gutiérrez JM. Characterization of events associated with apoptosis/anoikis induced by snake venom metalloproteinase BaP1 on human endothelial cells. J Cell Biochem. 2005 Feb 15;94(3):520-8.

67. You WK, Seo HJ, Chung KH, Kim DS. A novel metalloprotease from Gloydius halys venom induces endothelial cell apoptosis through its protease and disintegrin-like domains. J Biochem. 2003 Nov;134(5):739-49.

68. Wu WB, Chang SC, Liau MY, Huang TF. Purification, molecular cloning and mechanism of action of graminelysin I, a snake-venom-derived metalloproteinase that induces apoptosis of human endothelial cells. Biochem J. 2001 Aug 1;357(Pt 3):719-28.

69. Wu WB, Huang TF. Activation of MMP-2, cleavage of matrix proteins, and adherens junctions during a snake venom metalloproteinase-induced endothelial cell apoptosis. Exp Cell Res. 2003 Aug 1;288(1):143-57.

70. Achê DC, Gomes MSR, de Souza DLN, Silva MA, Brandeburgo MIH, Yoneyama KAG, Rodrigues RS, Borges MH, Lopes DS, Rodrigues. Biochemical properties of a new PI SVMP from Bothrops pauloensis: inhibition of cell adhesion and angiogenesis. Int J Biol Macromol. 2015 In;72:445-53.

71. Suhr SM, Kim DS. Identification of the snake venom substance that induces apoptosis. Biochem Biophys Res Commun. 1996 Jul 5;224(1):134-9.

72. Torii S, Naito M, Tsuruo T. Apoxin I, a novel apoptosis-inducing factor with L-amino acid oxidase activity purified from Western diamondback rattlesnake venom. J Biol Chem. 1997 Apr 4;272(14):9539-42.

73. Wei JF, Yang HW, Wei XL, Qiao LY, Wang WY, He SH. Purification, characterization and biological activities of the L-amino acid oxidase from Bungarus fasciatus snake venom. Toxicon. 2009 Sep 1;54(3):262-71.

74. Wu WB, Peng HC, Huang TF. Crotalin, a vWF and GP lb cleaving metalloproteinase from venom of Crotalus atrox. Thromb Haemost. 2001 Dec;86(12):1501-11

75. Tseng YL, Wu WB, Hsu CC, Peng HC, Huang TF. Inhibitory effects of human alpha2- macroglobulin and mouse serum on the PSGL-1 and glycoprotein lb proteolysis by a snake venom metalloproteinase, triflamp. Toxicon. 2004 Jun 1;43(7)769-77.

76. Cintra ACO, De Toni LGB, Sartim MA, Franco JJ, Caetano RC, Murakami MT, Sampaio SV. Batroxase, a new metalloproteinase from B. atrox snake venom with strong fibrinolytic activity. Toxicon. 2012 Jul;60(1):70-82.

77. Bernardes CP, Menaldo DL, Camacho E, Rosa JC, Escalante T, Rucavado A, Lomonte B, Gutiérrez JM, Sampaio SV. Proteomic analysis of Bothrops pirajai snake venom and characterization of BpirMP, a new PI metalloproteinase. J Proteomics. 2013 Mar 27;80:250-67.

78. Rodrigues RS, da Silva JF, França JB, Fonseca FPP, Otaviano AR, Silva FH, Hamaguchi A, Magro AJ, Braz ASK, dos Santos JI, Homsi-Brandeburgo, MI, Fontes MRM, Fuly AL, Soares AM, Rodrigues VM. Structural and functional properties of Bp-LAAO, a new L-amino acid oxidase isolated from Bothrops pauloensis snake venom. Biochimie. 2009 Apr;91(4):490-501.

79. Bregge-Silva C, Nonato MC, de Albuquerque S, Ho PL, de Azevedo ILMJ, Diniz MRV, Lomonte B, Rucavado A, Díaz C, Gutiérrez JM, Arantes EC. Isolation and biochemical, functional and structural characterization of a novel L-amino acid oxidase from Lachesis muta snake venom. Toxicon. 2012 Dec 1;60(7):1263-76 